\title{
OPTIMIZING TECHNOLOGY TO REDUCE MERCURY AND ACID GAS EMISSIONS FROM ELECTRIC POWER PLANTS
}

\author{
Semi-Annual Report \\ August 1, 2004 to January 31, 2005
}

Principal Authors Jeffrey C. Quick David E. Tabet Sharon Wakefield Roger L. Bon

Published February 2005

Prepared for The United States Department of Energy Contract No. DE-FG26-03NT41901

Contract Officer Sara M. Pletcher

National Energy Technology Laboratory Morgantown, West Virginia

Prepared by The Utah Geological Survey 1594 West North Temple, Suite 3110 Salt Lake City, Utah 84114-6100 (801) 537-3300 


\section{DISCLAIMER}

This report was prepared as an account of work sponsored by an agency of the United States Government. Neither the United States Government nor any agency thereof, nor any of their employees, makes any warranty, express or implied, or assumes any legal liability or responsibility for the accuracy, completeness, or usefulness of any information, apparatus, product, or process disclosed, or represents that its use would not infringe privately owned rights. Reference herein to any specific commercial product, process, or service by trade name, trademark, manufacturer, or otherwise does not necessarily constitute or imply its endorsement, recommendation, or favoring by the United States Government or any agency thereof. The views and opinions of authors expressed herein do not necessarily state or reflect those of the United States Government or any agency thereof.

Although this product represents the work of professional scientists, the Utah Department of Natural Resources, Utah Geological Survey, makes no warranty, express or implied, regarding its suitability for a particular use. The Utah Department of Natural Resources, Utah Geological Survey, shall not be liable under any circumstances for any direct, indirect, special, incidental, or consequential damages with respect to claims by users of this product. 


\begin{abstract}
Revised maps and associated data show potential mercury, sulfur, and chlorine emissions for U.S. coal by county of origin. Existing coal mining and coal washing practices result in a $25 \%$ reduction of mercury in U.S. coal before it is delivered to the power plant. Selection of low-mercury coal is a good mercury control option for plants having hot-side ESP, cold-side ESP, or hot-side ESP/FGD emission controls. Chlorine content is more important for plants having cold-side ESP/FGD or SDA/FF controls; optimum net mercury capture is indicated where chlorine is between 500 and 1000 ppm. Selection of low-sulfur coal should improve mercury capture where carbon in fly ash is used to reduce mercury emissions.
\end{abstract}




\section{TABLE OF CONTENTS}

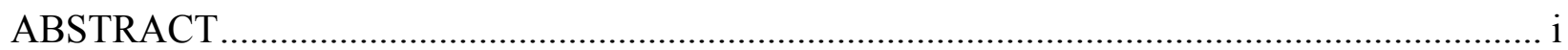

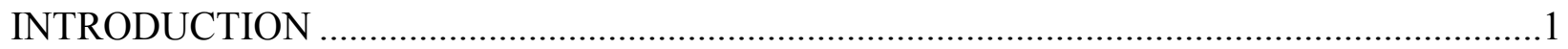

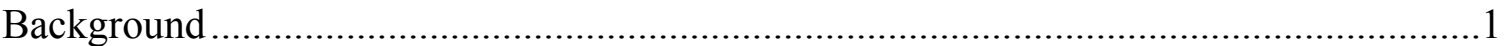

Scope

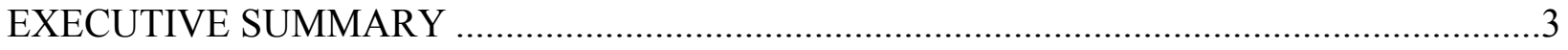

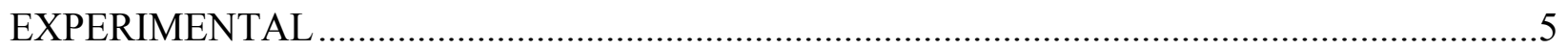

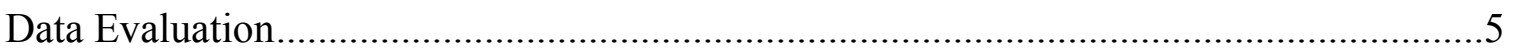

Revisions to Draft Maps ………………...............................................................

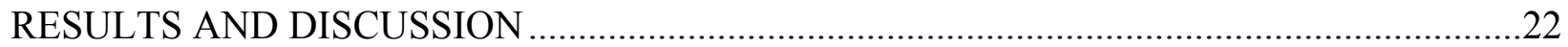

Selecting the Best Equation to Predict Mercury Capture ...............................................22

Comparison of Existing Technologies: Implications for Mercury Control .......................23

The Relationship Between Coal Sulfur and Mercury Capture ...........................................25

In-Ground Coal Mercury Compared to Commercial Coal Mercury ..................................28

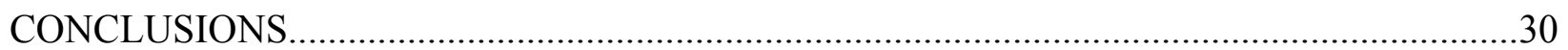

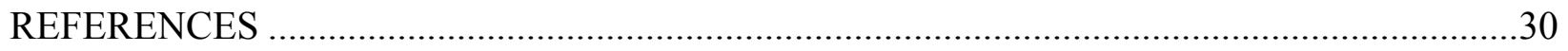

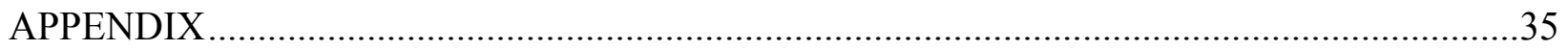

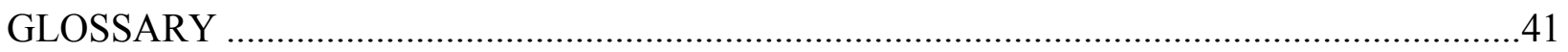

\section{FIGURES}

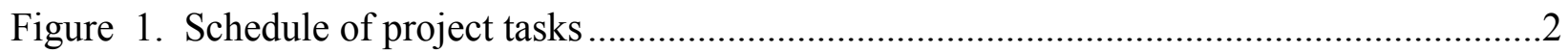

Figure 2. Three equations predict different amounts of mercury capture for SDA/FF

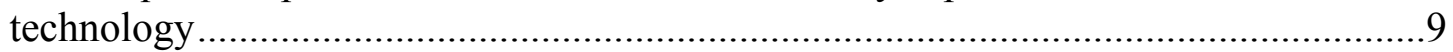

Figure 3. Three equations predict different amounts of mercury capture for cESP/FGD

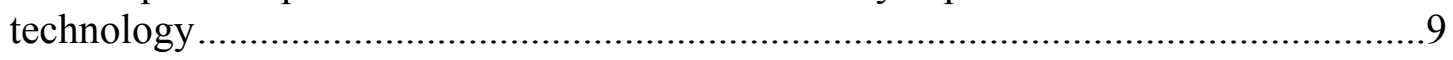

Figure 4. Three equations predict different amounts of mercury capture for hESP/FGD technology.....

Figure 5. Three equations predict different amounts of mercury capture for cESP technology.

Figure 6. Three equations predict different amounts of mercury capture for hESP technology

Figure 7. Potential uncontrolled sulfur emissions from coal .................................................12

Figure 8. Potential uncontrolled mercury emissions from coal ..................................................13 
Figure 9. Potential uncontrolled chlorine emissions from coal

Figure 10. Predicted mercury emissions for coal burned in electric utilities with Hot-Side, Electrostatic Precipitators

Figure 11. Predicted mercury emissions for coal burned in electric utilities with Cold-Side, Electrostatic Precipitators

Figure 12. Predicted mercury emissions for coal burned in electric utilities with Hot-Side, Electrostatic Precipitators and wet Flue Gas Desulphurization

Figure 13. Predicted mercury emissions for coal burned in electric utilities with Cold-Side, Electrostatic Precipitators and wet Flue Gas Desulphurization controls .

Figure 14. Predicted mercury emissions for coal burned in electric utilities with Spray-Dry Adsorption and Fabric Filter controls

Figure 15. Predicted mercury emission rate for coal burned in electric utilities with Cold-Side, Electrostatic Precipitators and wet Flue Gas Desulphurization controls .

Figure 16. Predicted mercury emission rate for coal burned in electric utilities with Spray-Dry Adsorption and Fabric Filter controls

Figure 17. Mercury capture predicted for 162 U.S. counties increases with increasing coal chlorine for five existing control technologies

Figure 18. Decreasing mercury capture with increasing coal sulfur

Figure 19. Commercial coal from some areas has more mercury than what might be expected based on in-ground coal assays

\section{TABLES}

Table 1. Coal production from counties not represented in the ICR 2 data...............................6

Table 2. Technology-specific equations that predict mercury capture .......................................

Table 3. Comparison of mercury control technologies............................................................25 


\section{INTRODUCTION}

\section{Background}

Switching to low-mercury-emission coal may be an effective strategy to comply with impending regulations that are intended to reduce mercury emissions from electric utilities. For example, despite proven emission control technology, burning low-sulfur coal is the most popular method to reduce sulfur emissions. Because technology to reduce mercury emissions is less certain, burning low-mercury coal is a likely method to reduce mercury emissions. Like sulfur, the amount of mercury in U.S. coal shows substantial geographic variation. However, unlike sulfur, mercury emissions also vary with the abundance of other elements in the coal, such as chlorine and sulfur, which influence mercury capture by emission control technologies. Consequently, mercury emission factors vary according to the relative abundance of several elements in the coal, and are specific to different emission control technologies.

This project uses Geographic Information System technology (ArcView GIS) to create detailed maps to show where U.S. coal with low-mercury and acid-gas emissions might be found. The map series will show geographic variation of mercury, chlorine, and sulfur in coal, as well as the mercury emission penalty, calculated for data aggregated by U.S. county-of-origin using equations specific to power plants classified by boiler type and flue gas emission controls. Removing mercury from flue gas is a technically complex task - different technologies will be required for different coals. Maps showing the geographic variation of mercury and acid-gas emission factors for U.S. coal will help locate the best coal for each technology and identify the best technology for each coal. 
Coal quality data used in this study were described in a previous report (Quick and others, 2004a). Briefly, these data were selected from five data sets and include: 19,507 FERC 423 data records (USEIA, 2003a), 25,818 ICR data records (USEPA, 2003), 5602 CTRDB data records (USEIA, 2003b), 5045 COALQUAL data records (Bragg and others, 1997), and 73 PSU-DOE data records (Anonymous, 1990; Davis and Glick, 1993; Scaroni and others, 1999). Additional data considered in this report are from CEA (2004) and USMSHA (2004).

\section{Scope}

This report describes the progress made during the third six-month period of this 24month project (figure 1). Results from task 6, and observations made while preparing a presentation (Quick and others, 2005) are described and discussed.

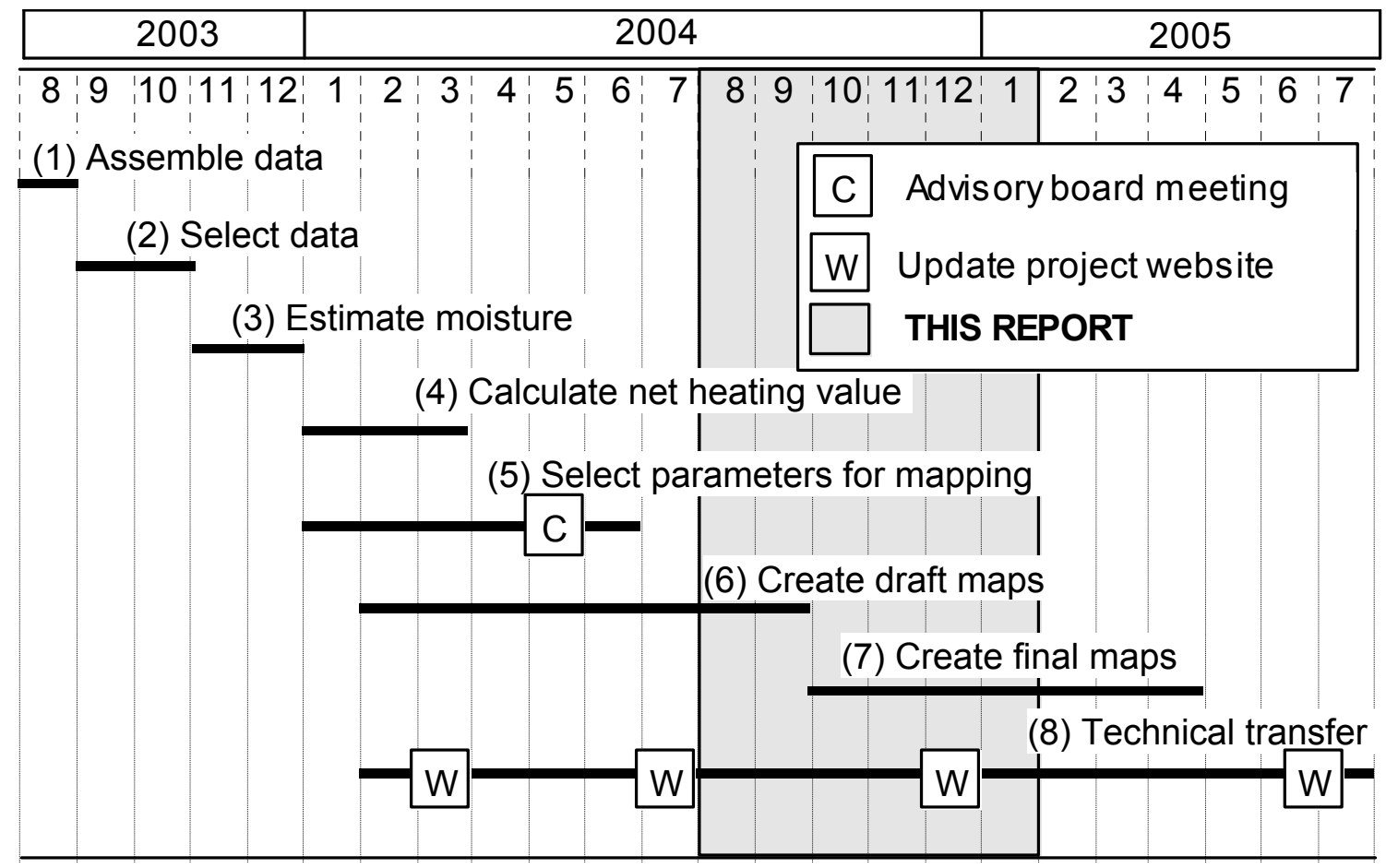

Figure 1. Schedule of project tasks. 


\section{EXECUTIVE SUMMARY}

Revised, draft maps showing the geographic variation of mercury and acid-gas emission factors for U.S. coal by county of origin are presented, together with associated coal assay data. Three revisions to the maps presented in our August report (Quick and others, 2004b) include the following:

- ICR 2 coal assay data were identified for Panola/Rusk and Titus Counties Texas; although these records lack county-of-origin names, they correspond to a utility that burns local coal.

- New information suggests that the mercury assay values listed in the ICR 2 data for most coals from the Gulf Coast province are erroneously low. Where possible, new mercury values have been estimated for affected counties.

- Maps showing technology-specific mercury emission potentials were revised; the revised maps are now based on the average result of three predictive equations, rather than the result from just one equation.

Using the average mercury emission factors obtained from three equations, county-specific coal assay data, and estimates of 1999 county coal production, mercury capture is estimated for five existing emission control technologies (hot- side electrostatic precipitator [hESP], cold-side electrostatic precipitator [cESP], hot-side electrostatic precipitator with wet flue-gas desulfurization [hESP/FGD], cold-side electrostatic precipitator with wet flue-gas desulfurization [cESP/FGD], and spray-dry adsorption with fabric filter [SDA/FF] controls). A comparison of in-ground coal mercury to produced coal mercury was also made. Finally, empirical data from the Canadian Electricity Association (CEA, 2004) were used to evaluate the negative correlation between coal sulfur content and mercury capture. The results indicate: 
- Selection of low-mercury coal is a reasonable way to reduce mercury emissions from units equipped with hESP, cESP, or hESP/FGD controls, whereas selection of coal with highchlorine content is a better option for units with $\mathrm{cESP} / \mathrm{FGD}$, or SDA/FF controls.

- Blending high- and low-chlorine coals to an optimum level between 500 and 1000 ppm chlorine should provide a net reduction of mercury emissions for units with cESP/FGD, or $\mathrm{SDA} / \mathrm{FF}$ controls.

- Although coal shipped to utilities contains about $25 \%$ less mercury than the in-ground resource, this difference is not geographically uniform. With the notable exception of Powder River Basin (PRB) coal from Wyoming, the mercury content of commercial coal from the western U.S., as well as Ohio, northern Pennsylvania, and the Gulf Coast, is similar or greater than the in-ground coal resource. Coal washing might be an effective mercury mitigation strategy in these areas.

- Selection of low-sulfur coal may improve mercury capture where carbon in fly ash is used to reduce mercury emissions. 


\section{EXPERIMENTAL}

Work accomplished during this reporting period included data evaluation and revisions to draft maps. Related observations made while preparing for a conference presentation (Quick and others, 2005) are discussed.

\section{Data Evaluation}

Comparison of ICR 2 county origins, with 1999 county coal production (USEIA 2003a; USMSHA, 2004) showed that not all coal-producing counties are represented in the ICR data. This deficiency was especially acute for counties in Texas. Accordingly, 85 ICR 2 data records originating from the Martin Lake power station (but lacking county-of-origin information) were assigned to Panola and Rusk Counties, Texas. Likewise, 87 records from the Monticello station were assigned to Titus County. Notably, the Monticello records may include coal originating from nearby Hopkins County.

Comments to the USEPA related to the proposed mercury reduction rule (McCall, 2004; Eutizi, 2005; Glacken, 2005) suggest that the mercury values reported in the ICR 2 data for most Gulf Coast coal are erroneously low. Accordingly, average mercury values, from ICR 3 testing ${ }^{1}$ or newly reported values (McCall, 2004; Eutizi, 2005), were used to estimate county-average mercury values for coal from Panola, Titus, Atascosa, Freestone, Milam, and Robertson Counties, Texas. Mercury values for Leon County, Texas, as well as Red River and De Soto Parishes, Louisiana, have not been revised and are probably too low.

\footnotetext{
${ }^{1}$ The ICR 3 data originate from measurements of atmospheric mercury emissions from about 80 selected U.S. power plants (USEPA, 2003). The data show measured mercury emissions and mercury capture observed during three, multiple hour intervals for each plant, and are complementary to the more comprehensive ICR 2 coal assay data.
} 
Examination of coal supplier names listed in the ICR data identified nine records for coal from Washington County, Illinois, and seven records from Schuylkill County, Pennsylvania; these counties are now represented in the selected ICR 2 data. Table 1 lists the remaining counties missing from the selected ICR 2 data, together with their 1999 coal production. The missing counties represent 15.7 million tons, which is less than $2 \%$ of 1999 U.S. coal production.

Table 1. Coal production from counties not represented in the ICR 2 data selected for this study.

\begin{tabular}{|c|c|c|}
\hline State & County & 1999 production (tons) \\
\hline Alabama & Bibb & 44,500 \\
\hline Alabama & Cullman & 35,700 \\
\hline Alabama & Marion & 35,700 \\
\hline Alabama & Winston & 338,500 \\
\hline Arkansas & Johnson & 14,600 \\
\hline Colorado & Fremont & 242,200 \\
\hline Colorado & La Plata & 245,700 \\
\hline Illinois & Christian & 72,200 \\
\hline Indiana & Dubois & 72,800 \\
\hline Indiana & Spencer & 204,400 \\
\hline Kentucky & Knox & 506,100 \\
\hline Mississippi & Choctaw & 18,400 \\
\hline Missouri & Barton & 73,000 \\
\hline Ohio & Gallia & 220,600 \\
\hline Ohio & Monroe & 489,600 \\
\hline Ohio & Muskingum & 663,100 \\
\hline Ohio & Noble & 689,800 \\
\hline Ohio & Stark & 316,400 \\
\hline Oklahoma & Craig & 194,100 \\
\hline Pennsylvania & Carbon & 39,300 \\
\hline Pennsylvania & Clarion & 418,100 \\
\hline Pennsylvania & Jefferson & $1,119,100$ \\
\hline Pennsylvania & Lawrence & 84,800 \\
\hline Pennsylvania & Sullivan & 47,100 \\
\hline Pennsylvania & Venango & 91,600 \\
\hline Texas & Hopkins & $2,126,100$ \\
\hline Texas & Webb & 235,000 \\
\hline Virginia & Tazewell & $2,062,700$ \\
\hline West Virginia & McDowell & $4,698,900$ \\
\hline West Virginia & Mineral & 48,500 \\
\hline West Virginia & Tucker & 172,423 \\
\hline Wyoming & Sheridan & 76,400 \\
\hline
\end{tabular}




\section{Revisions to Draft Maps}

Various groups have used the ICR 3 utility emission data to derive equations that predict mercury capture for existing emission control technologies (Chu and others, 2000; Laumb and others, 2000; Roberson, 2002; ENSR, 2003; SAIC, 2003; AEMS, 2004). The equations use coal chlorine, ash, Btu, or sulfur values as independent variables to predict mercury capture. During the last reporting period, we applied selected equations to county-average coal assay data to create five technology-specific maps showing potential mercury emissions from U.S. coal. Because we lacked an independent utility emission data set to verify the selected equations, our selection of a single equation for each control technology was unavoidably arbitrary.

During the previous reporting period we also compared different equations that predict mercury emissions from units with SDA/FF emission controls. These equations all had similarly high reported $\mathrm{r}^{2}$ values, they all predicted increasing capture with increasing coal chlorine, but they also predicted different results when applied to the same, county-average coal assay data. Accordingly, all of the predictive equations originally considered in this study were re-examined to check for possible transcription errors, and to verify the reporting basis of the independent variables. The result of this effort is shown in table 2, which lists three different equations for each of the (5) emission control technologies examined in this study. Figures 1, 2, 3, 4, and 5 compare the mercury capture predicted by these equations for each control technology. These results extend our earlier finding of similar $\mathrm{r}^{2}$ values, similar trends, but different results, to include all five of the control technologies examined in this study (cESP, hsESP, hESP/FGD, cESP/FGD, and SDA/FF controls). 
Table 2. Technology-specific equations that predict mercury capture.

\begin{tabular}{|c|c|c|c|}
\hline $\begin{array}{l}\text { TECHNOLOGY } \\
\text { Reference } \\
\end{array}$ & Equation to Predict Mercury Capture $(100 \%$ capture $=1)$ & $r^{2}$ & $\mathrm{n}$ \\
\hline \multicolumn{4}{|l|}{ cESP } \\
\hline \multirow{2}{*}{ Roberson (2002) } & \multirow{2}{*}{$0.1133 \operatorname{Ln}\left(\frac{C l_{p p m, d r y}}{1.998 S_{w t . \%, d r y}}\right)-0.2987$} & \multirow{2}{*}{0.53} & \multirow{2}{*}{28} \\
\hline & & & \\
\hline model 2, SAIC (2003) & $1-\operatorname{Exp}\left(-7.33 E^{-2}-3.309\left(\right.\right.$ Ibs Cl per $\left.\left.10^{12} \mathrm{Btu}\right)\right)$ & 0.47 & 12 \\
\hline model 1 , SAIC (2003) & $1-\operatorname{Exp}\left(1.6374-0.18693 \operatorname{Ln}\left(\right.\right.$ Ibs Cl per $\left.\left.10^{12} \mathrm{Btu}\right)\right)$ & 0.38 & 12 \\
\hline \multicolumn{4}{|l|}{ cESP/FGD } \\
\hline Roberson (2002) & $0.1157 \operatorname{Ln}\left(C l_{p p m, d r y}\right)-0.1438$ & 0.70 & 11 \\
\hline model 1 , SAIC (2003) & $1-\operatorname{Exp}\left(1.8529-0.27149 \operatorname{Ln}\left(\right.\right.$ Ibs Cl per $10^{12}$ Btu $\left.)\right)$ & 0.74 & 8 \\
\hline model 3, SAIC (2003) & $1-\operatorname{Exp}\left(-0.2559-2.3343 E^{-5}\left(\frac{100 C l_{p p m, d r y}}{S_{w t . \%, d r y}}\right)\right)$ & 0.73 & 8 \\
\hline \multicolumn{4}{|l|}{ hESP } \\
\hline model 1 , SAIC (2003) & $1-\operatorname{Exp}\left(0.9451-9.995 E^{-2} \operatorname{Ln}\left(\right.\right.$ lbs Cl per $10^{12}$ Btu $\left.)\right)$ & 0.42 & 7 \\
\hline model 3, SAIC (2003) & $1-\operatorname{Exp}\left(0.0611-2.169 E^{-6}\left(\frac{100 C l_{p p m, d r y}}{S_{w t . \%, d r y}}\right)\right)$ & 0.54 & 7 \\
\hline ENSR (2003) & $1-\operatorname{Exp}\left(0.12124-1.021 E^{-4}\left(C l_{p p m, d r y}\right)\right)$ & 0.39 & 9 \\
\hline \multicolumn{4}{|l|}{ hESP/FGD } \\
\hline model 1 , SAIC (2003) & $1-\operatorname{Exp}\left(2.7019-0.29952 \operatorname{Ln}\left(\right.\right.$ Ibs Cl per $\left.\left.10^{12} \mathrm{Btu}\right)\right)$ & 0.75 & 6 \\
\hline model 2, SAIC (2003) & $1-\operatorname{Exp}\left(-3.59 E^{-2}-9.358 E^{-6}\left(\right.\right.$ Ibs Cl per $\left.\left.10^{12} \mathrm{Btu}\right)\right)$ & 0.67 & 6 \\
\hline model 4, SAIC (2003) & $1-\operatorname{Exp}\left(2.5618-0.268 L n\left(\frac{100 C l_{p p m, d r y}}{S_{w t . \%, d r y}}\right)\right)$ & 0.42 & 6 \\
\hline \multicolumn{4}{|l|}{ SDA/FF } \\
\hline Roberson (2002) & $0.2854 \operatorname{Ln}\left(C l_{p p m, d r y}\right)-1.1302$ & 0.91 & 10 \\
\hline model 1 , SAIC (2003) & $1-\operatorname{Exp}\left(10.7111-1.22628 \operatorname{Ln}\left(\right.\right.$ Ibs Cl per $\left.\left.10^{12} B t u\right)\right)$ & 0.89 & 10 \\
\hline ENSR (2003) & $1-\operatorname{Exp}\left(-0.19992-2.164 E^{-3}\left(C l_{p p m, d r y}\right)\right)$ & 0.94 & 10 \\
\hline
\end{tabular}

Notes,

cESP: cold-side Electrostatic Precipitator;

cESP/FGD: cold-side Electrostatic Precipitator with wet Flue Gas Desulphurization;

hESP: hot-side Electrostatic Precipitator;

hESP/FGD: hot-side Electrostatic Precipitator with wet Flue Gas Desulphurization;

SDA/FF: Spray Dry Adsorption with Fabric Filter. 

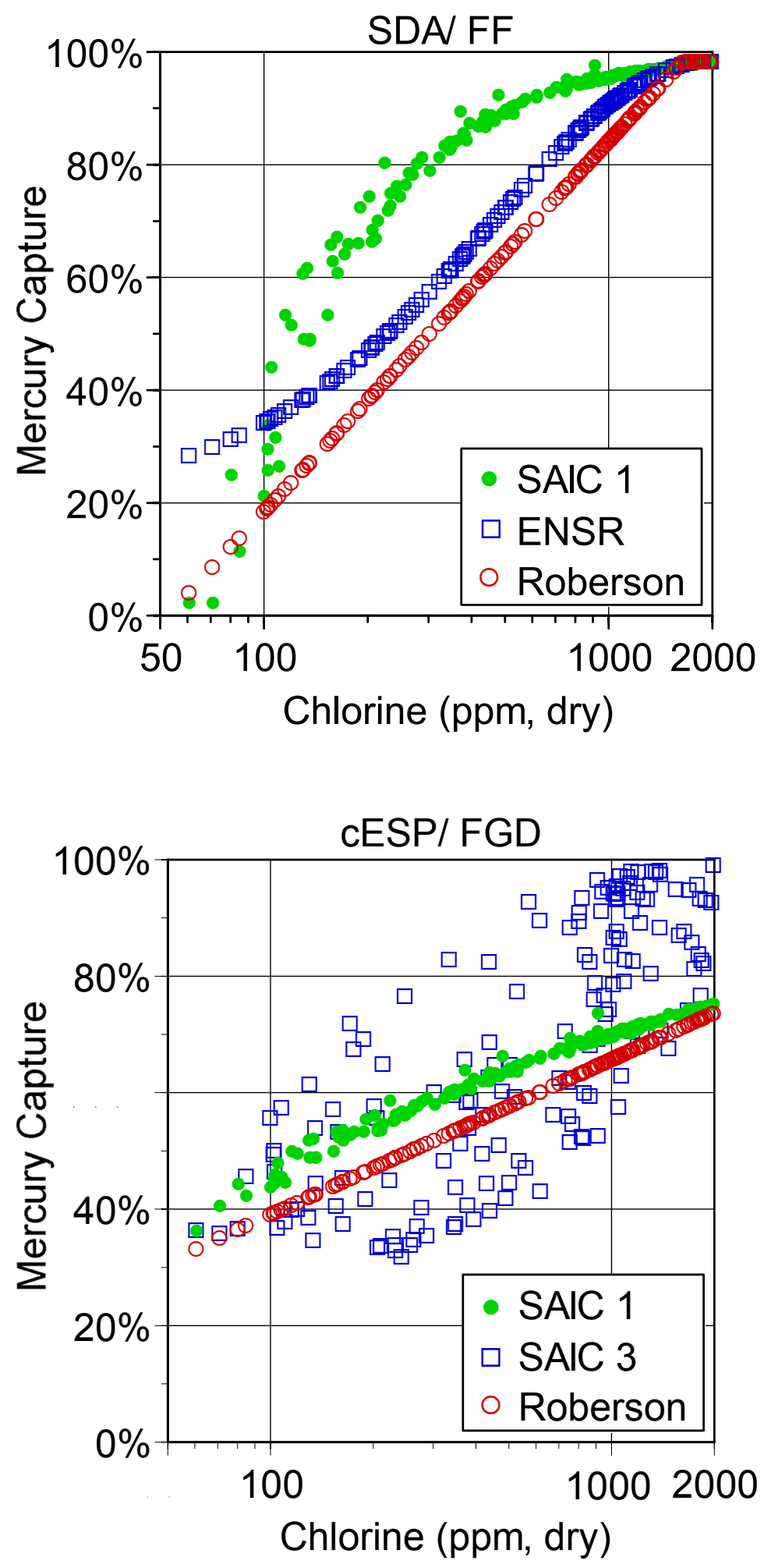

Figure 2. Three equations predict different amounts of mercury capture for SDA/FF technology when applied to data for 161 U.S. counties.

Notes, SDA/FF: Spray Dry Adsorption, Fabric Filter; SAIC (2003), ENSR (2003), and Roberson (2002) equations listed on table 2 (this report); ICR 2 county-average coal assay data (appendix); results for six counties with $>2000$ ppm chlorine and one county with $<50 \mathrm{ppm}$ chlorine are not shown; results limited to $2 \%$ minimum capture and $98 \%$ maximum capture.

Figure 3. Three equations predict different amounts of mercury capture for cESP/FGD technology when applied to data for 161 U.S. counties.

Notes, cESP/FGD: cold-side Electrostatic Precipitator, wet Flue Gas Desulphurization; SAIC (2003), and Roberson (2002) equations listed on table 2 (this report); ICR 2 countyaverage coal assay data (appendix); results for six counties with $>2000$ ppm chlorine and one county with $<50 \mathrm{ppm}$ chlorine are not shown; results limited to $2 \%$ minimum capture and $98 \%$ maximum capture. 

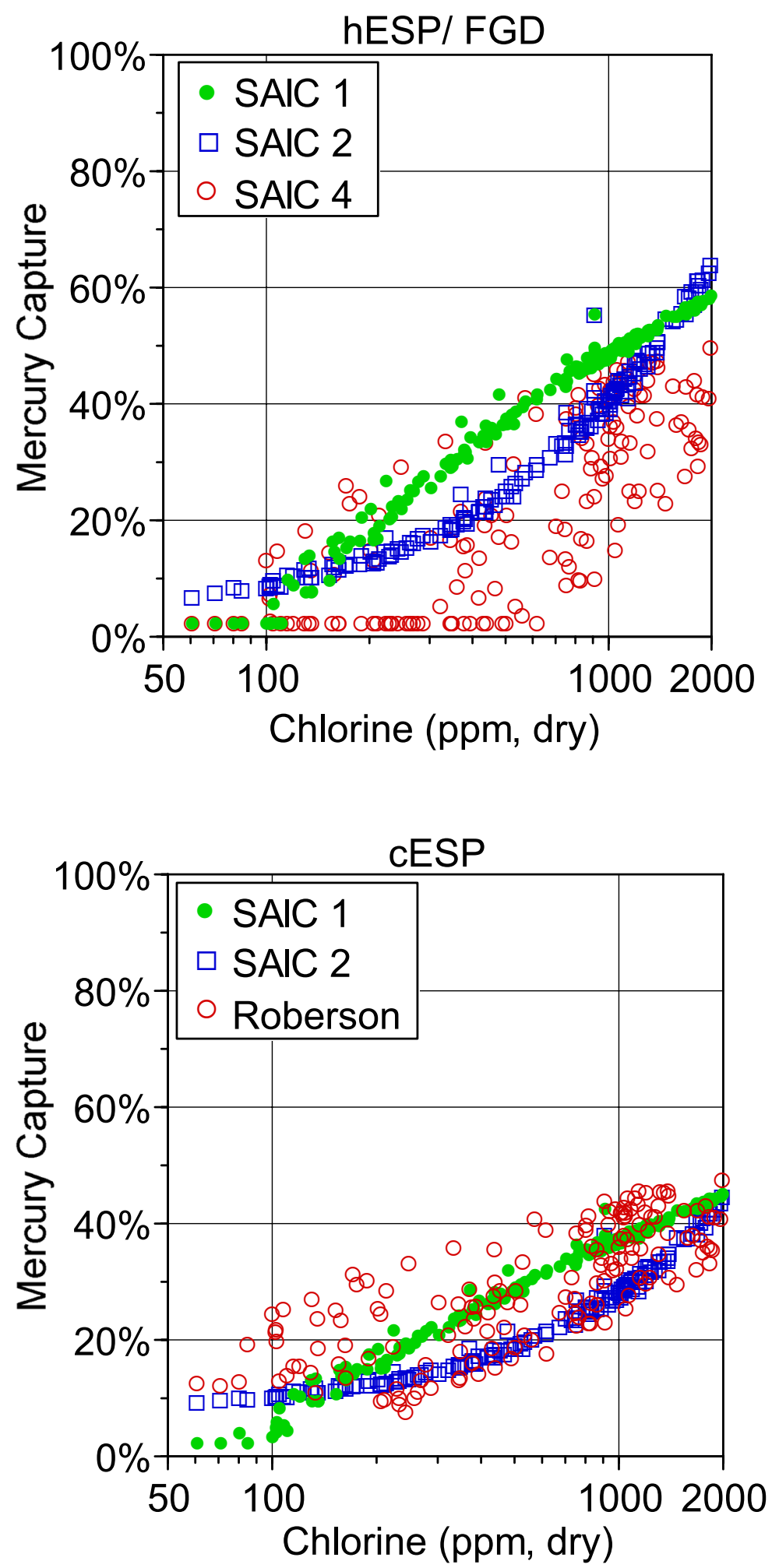

Figure 4. Three equations predict different amounts of mercury capture for hESP/FGD technology when applied to data for 161 U.S. counties.

Notes, hESP/FGD: hot-side Electrostatic Precipitator, wet Flue Gas Desulphurization; SAIC (2003) equations listed on table 2 (this report); ICR 2 county-average coal assay data (appendix); results for six counties with $>2000$ ppm chlorine and one county with $<50$ ppm chlorine are not shown; results limited to $2 \%$ minimum capture and $98 \%$ maximum capture.

Figure 5. Three equations predict different amounts of mercury capture for cESP technology when applied to data for 161 U.S. counties.

Notes, cESP: cold-side Electrostatic Precipitator; SAIC (2003), and Roberson (2002) equations listed on table 2 (this report); ICR 2 countyaverage coal assay data (appendix); results for six counties with $>2000$ ppm chlorine and one county with $<50$ ppm chlorine are not shown; results limited to $2 \%$ minimum capture and $98 \%$ maximum capture. 


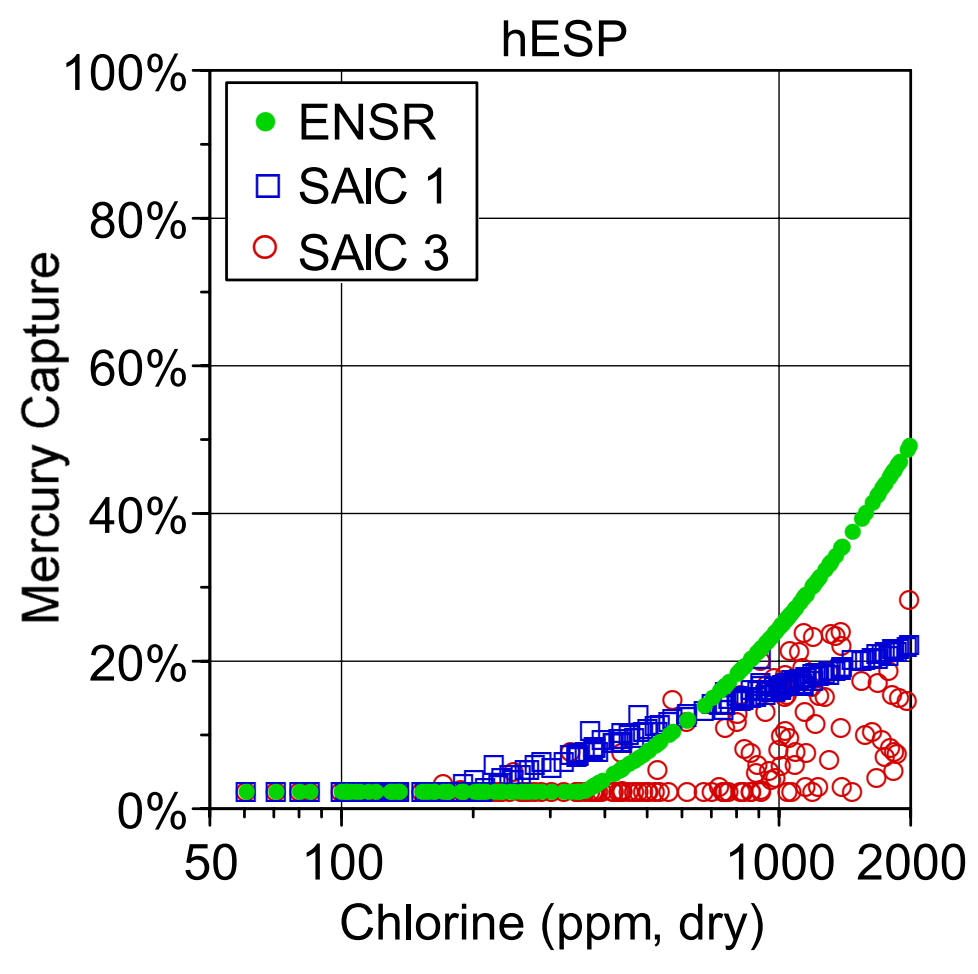

Figure 6. Three equations predict different amounts of mercury capture for hESP technology when applied to data for 161 U.S. counties.

Notes, hESP: hot-side Electrostatic Precipitator; ENSR (2003) and SAIC (2003) equations listed on table 2 (this report); ICR 2 county-average coal assay data (appendix); results for six counties with $>2000$ ppm chlorine and one county with $<50 \mathrm{ppm}$ chlorine are not shown; results limited to $2 \%$ minimum capture and $98 \%$ maximum capture.

The similar statistical significance but different county-specific results for the equations listed in table 2, coupled with the lack of a verification data set, makes selection of the best equation for each technology group largely arbitrary. Lacking objective criteria to select a single best equation, we chose to use the average result obtained from all three equations.

As might be expected, using the average result from three equations (rather than just one), adding data for more counties, and correcting erroneously low-mercury values for Gulf Coast coal, changed the maps being made for this project. Figures 7 through 16 show the revised draft maps, which more closely correspond to the final maps that are currently being constructed. 


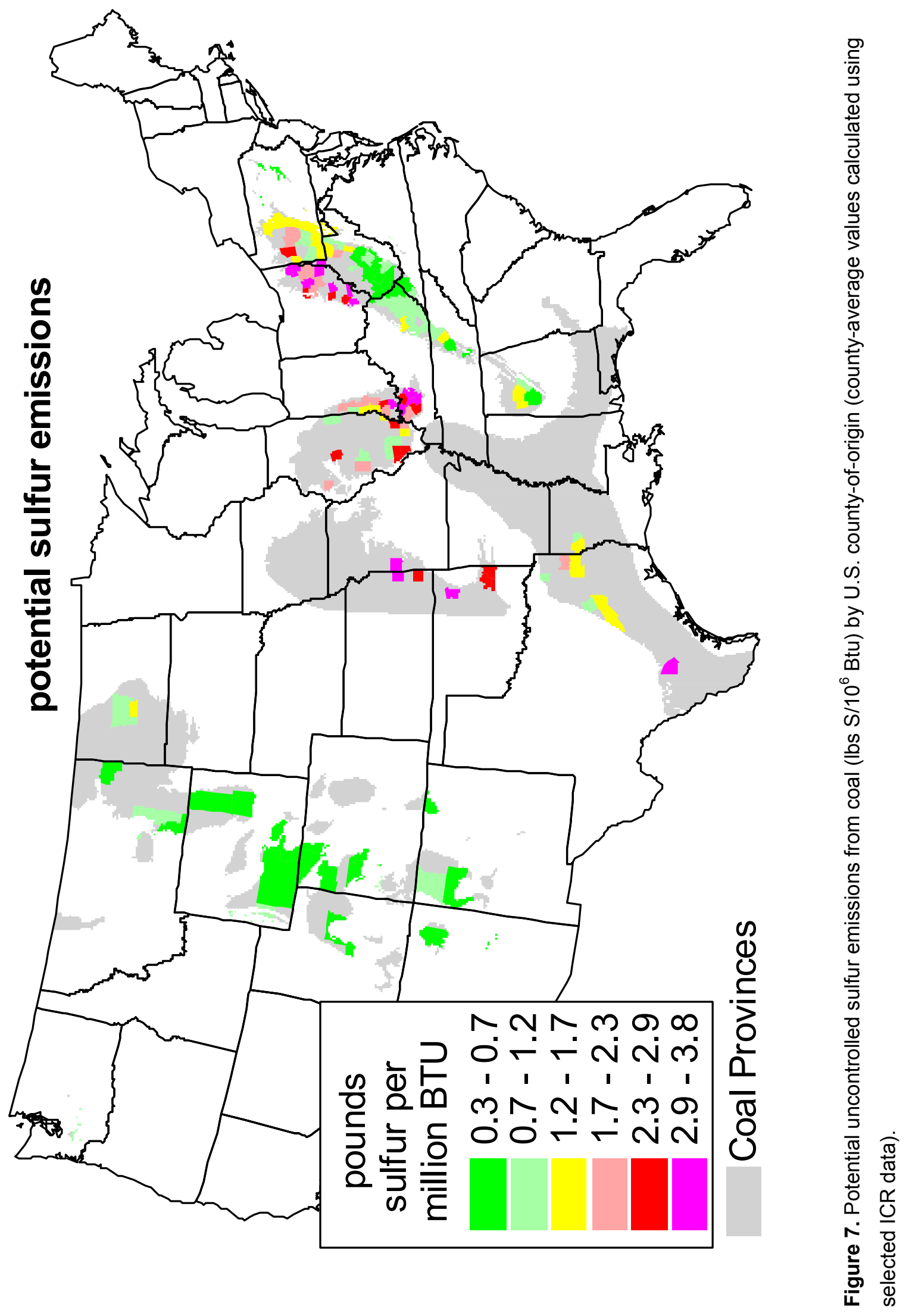




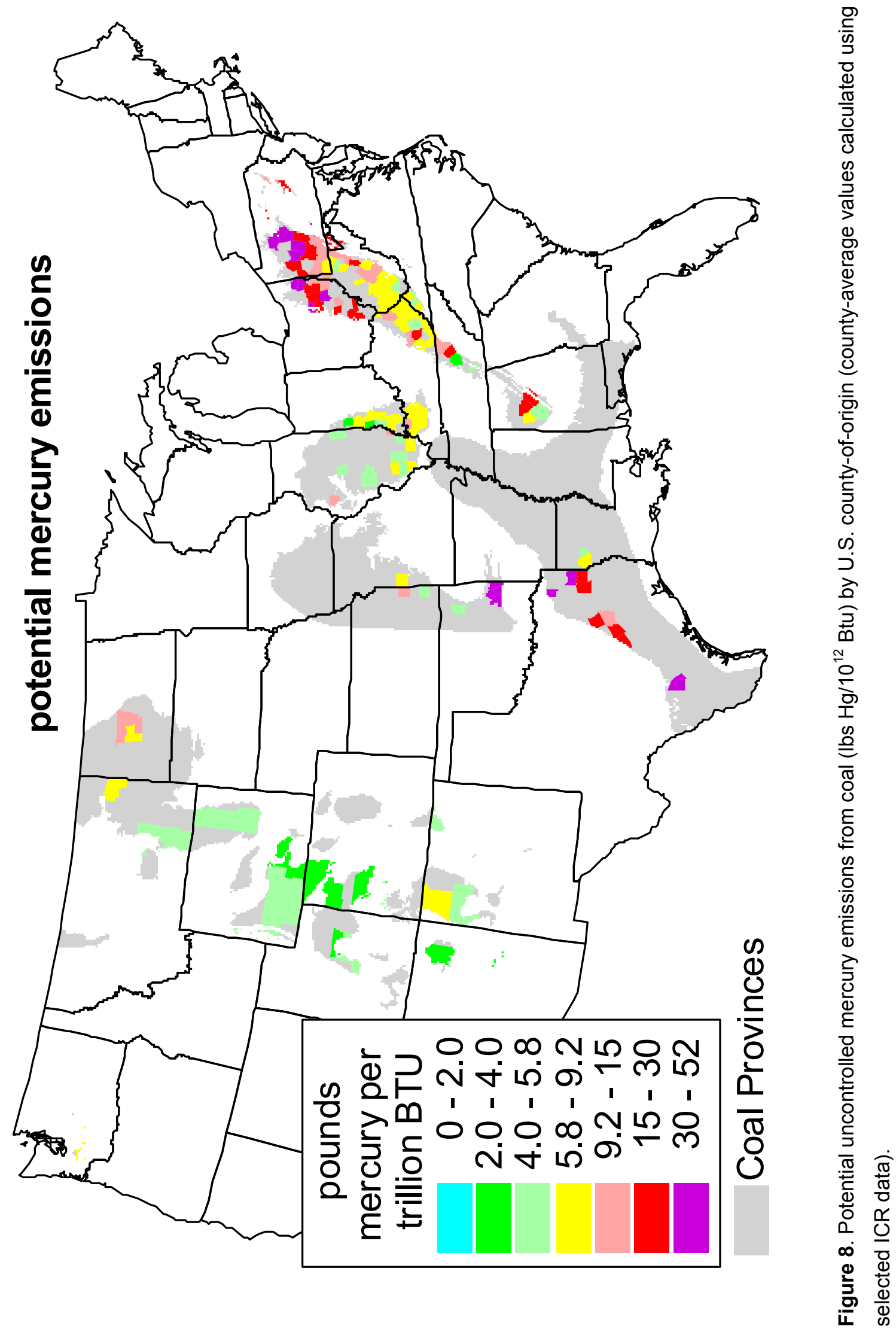




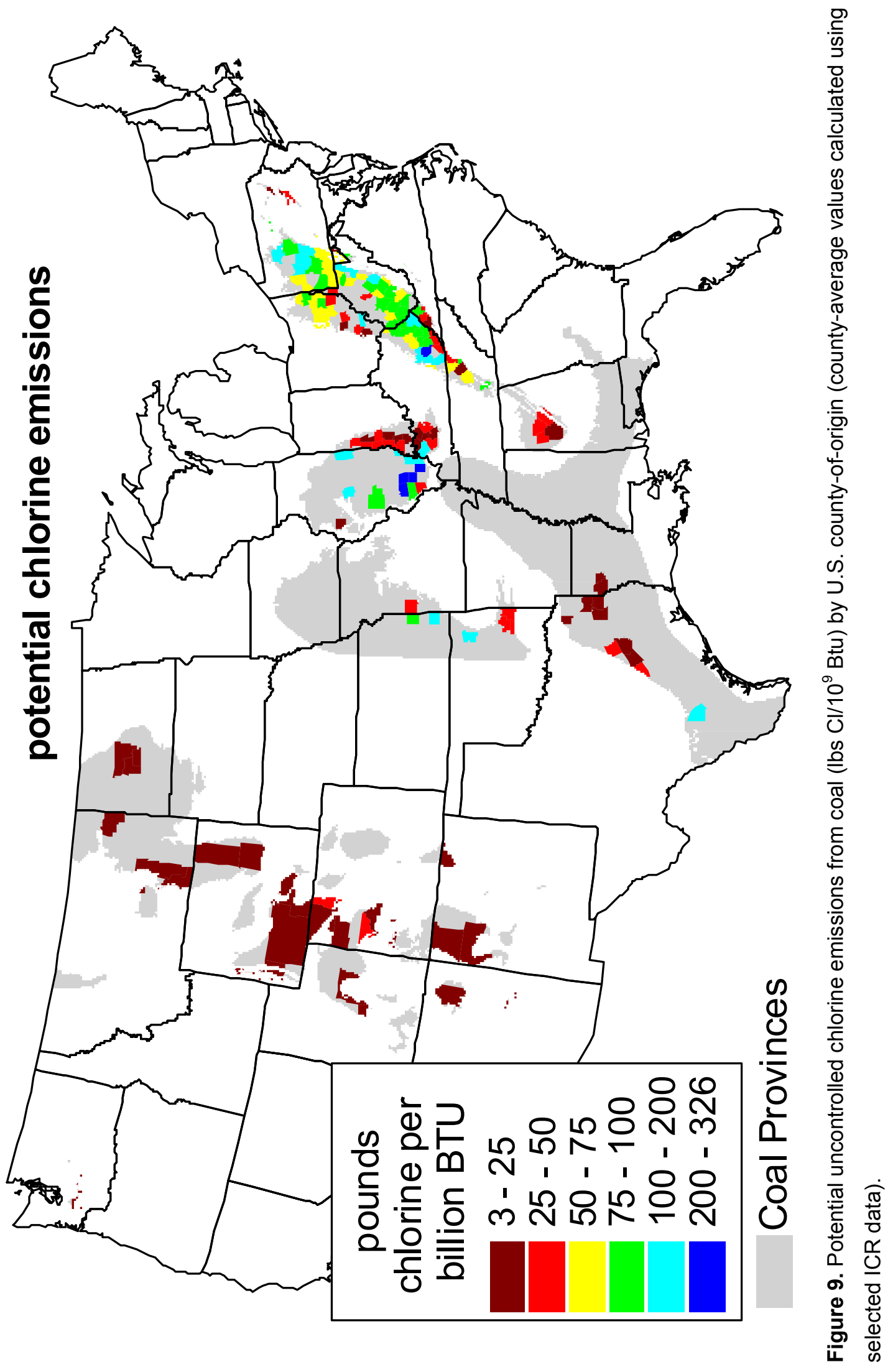




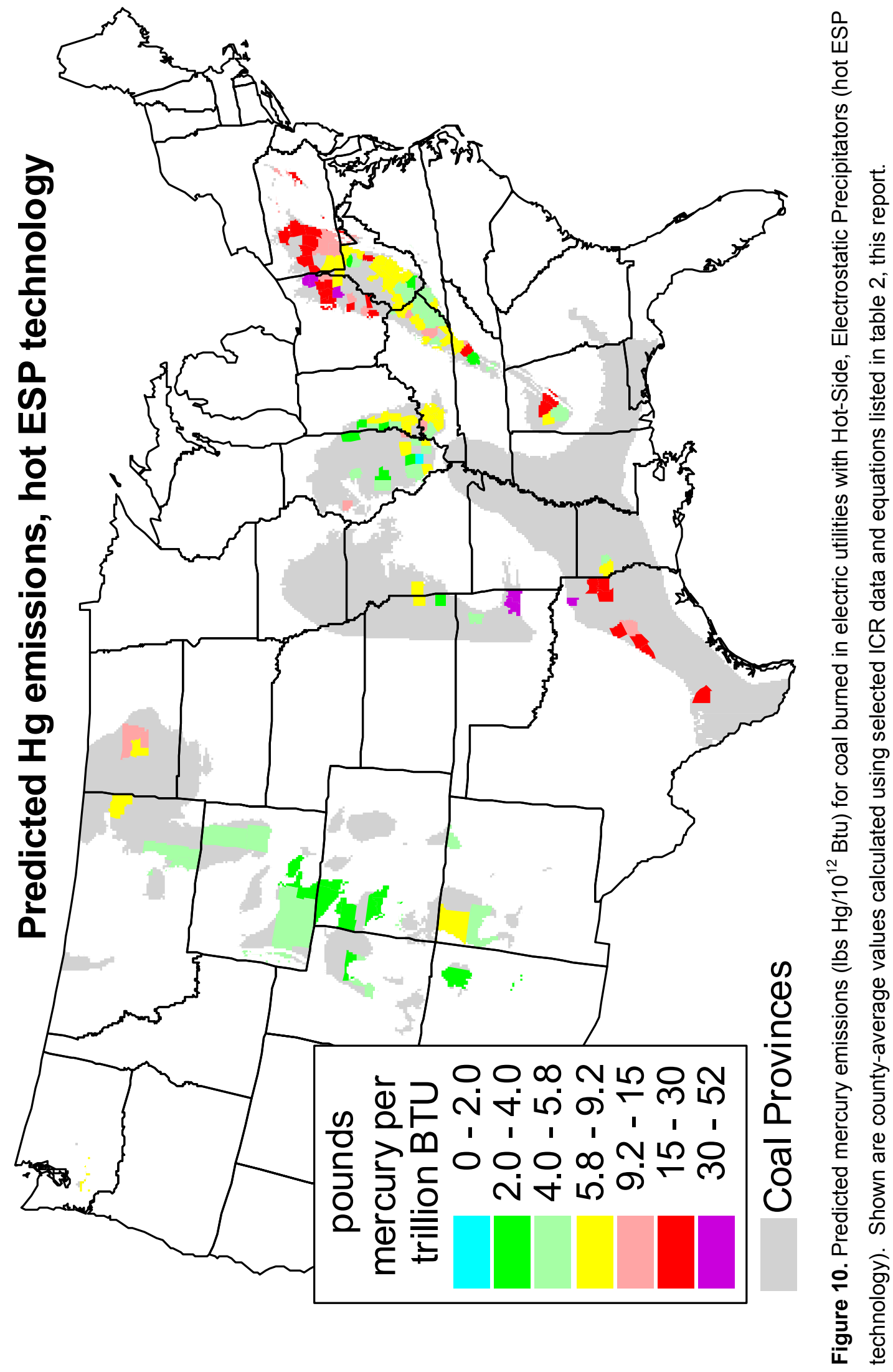




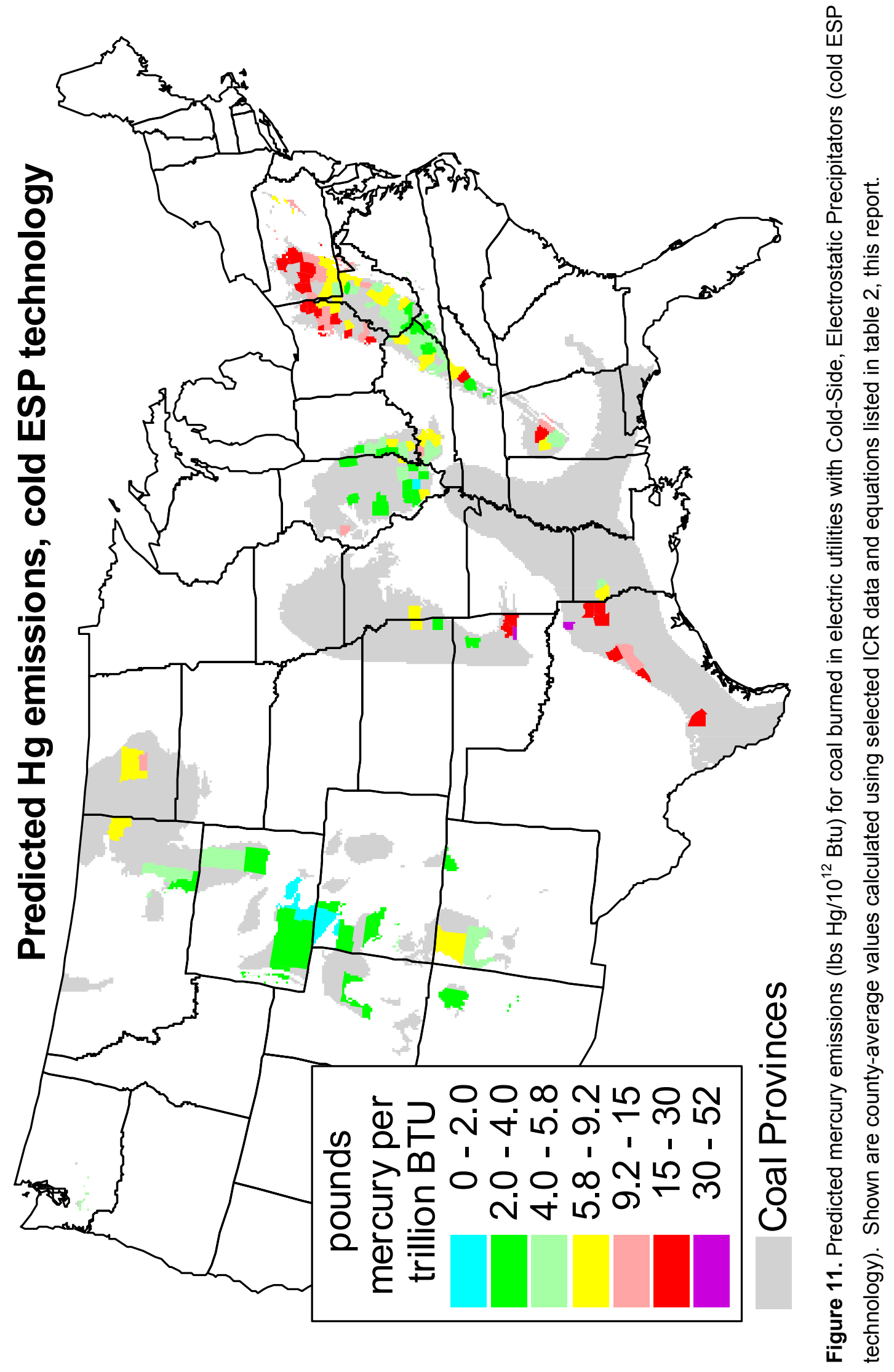



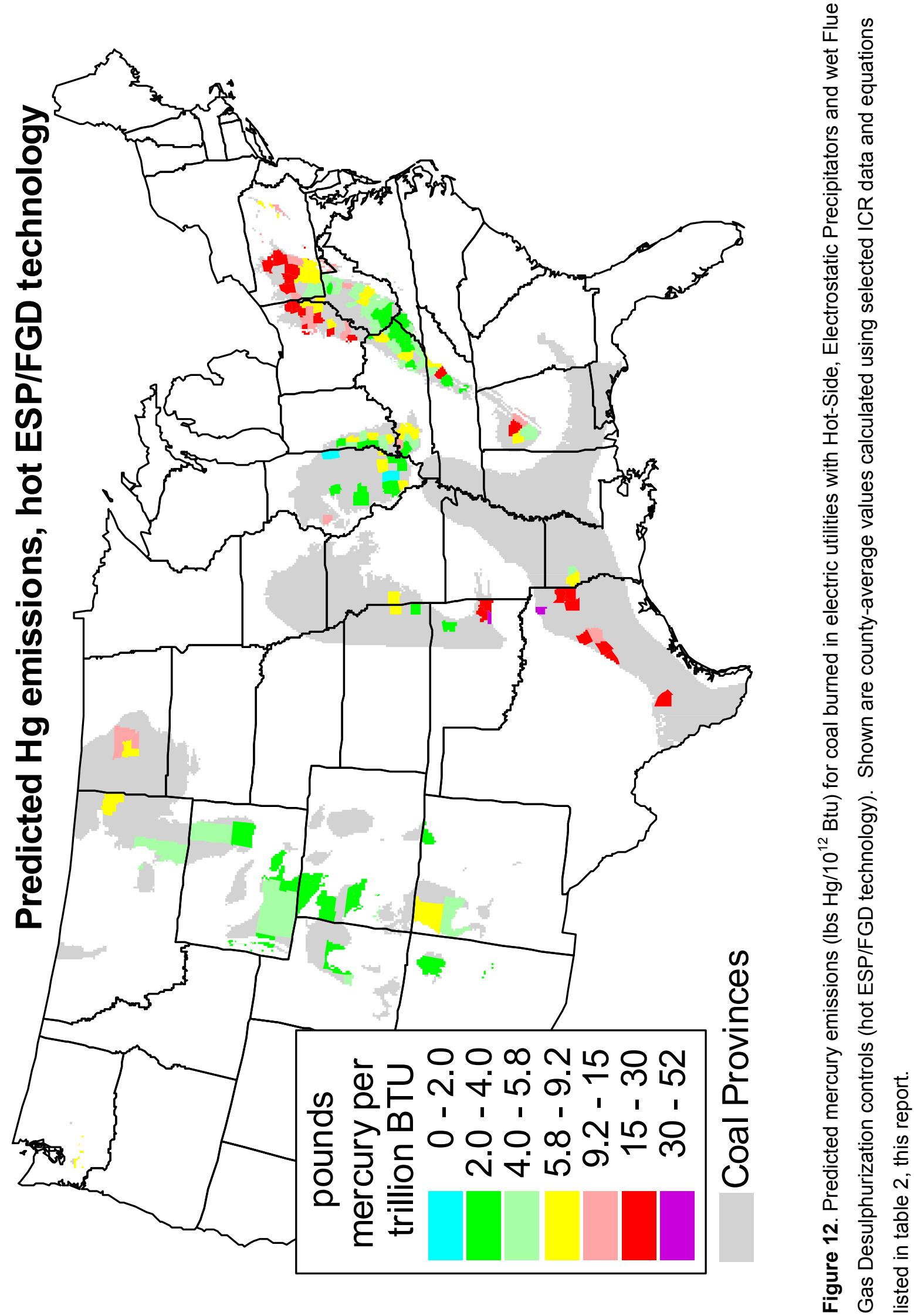


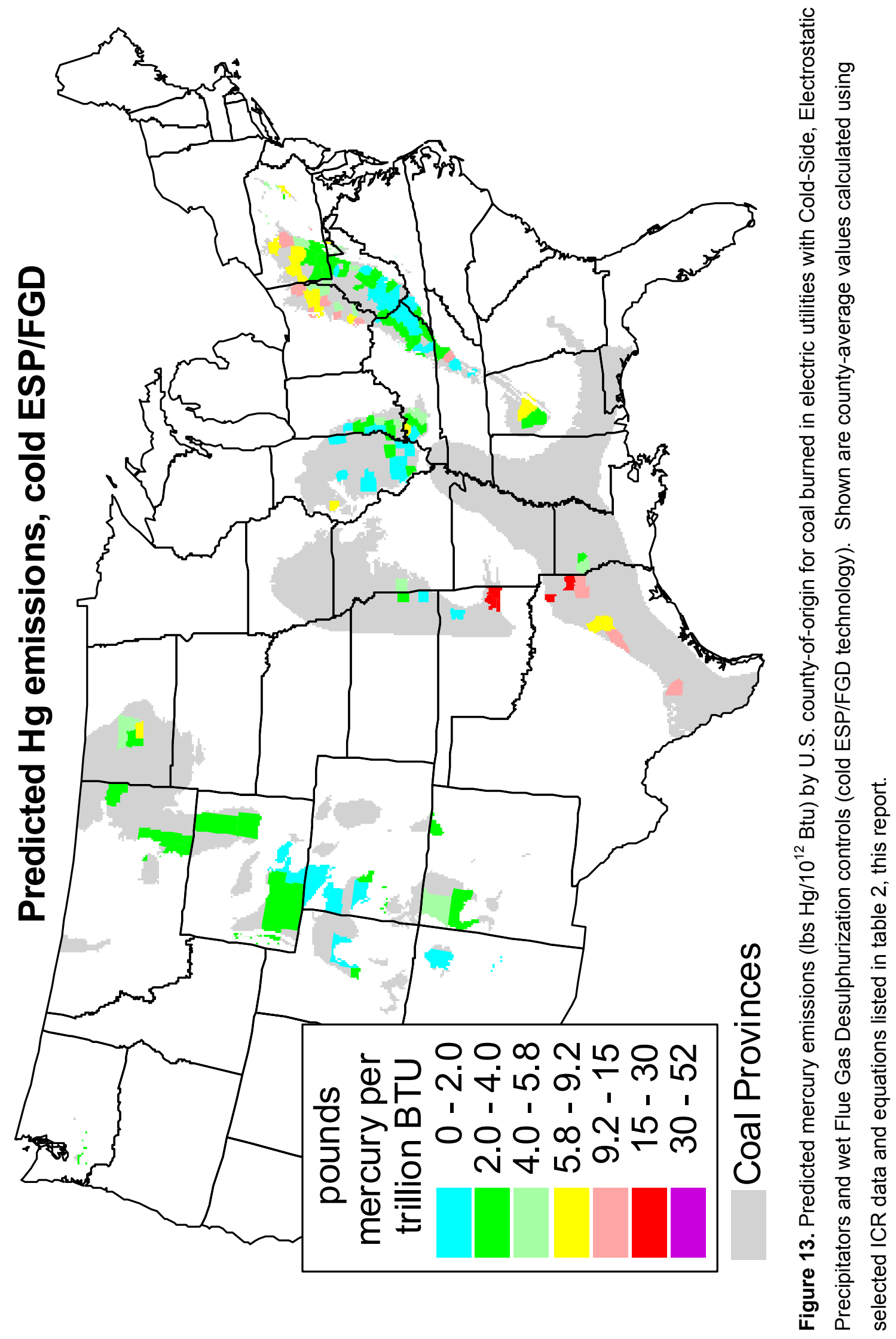




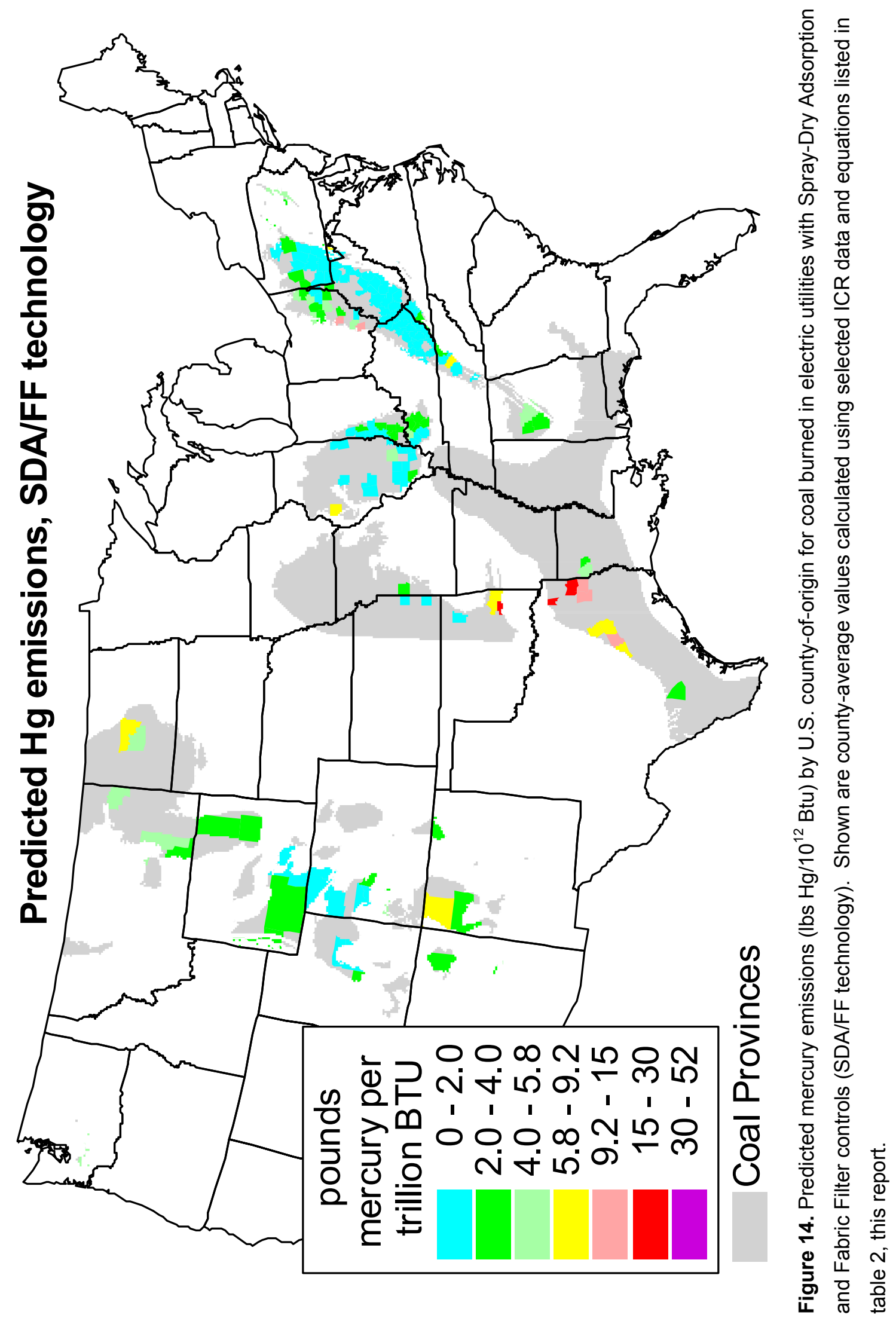




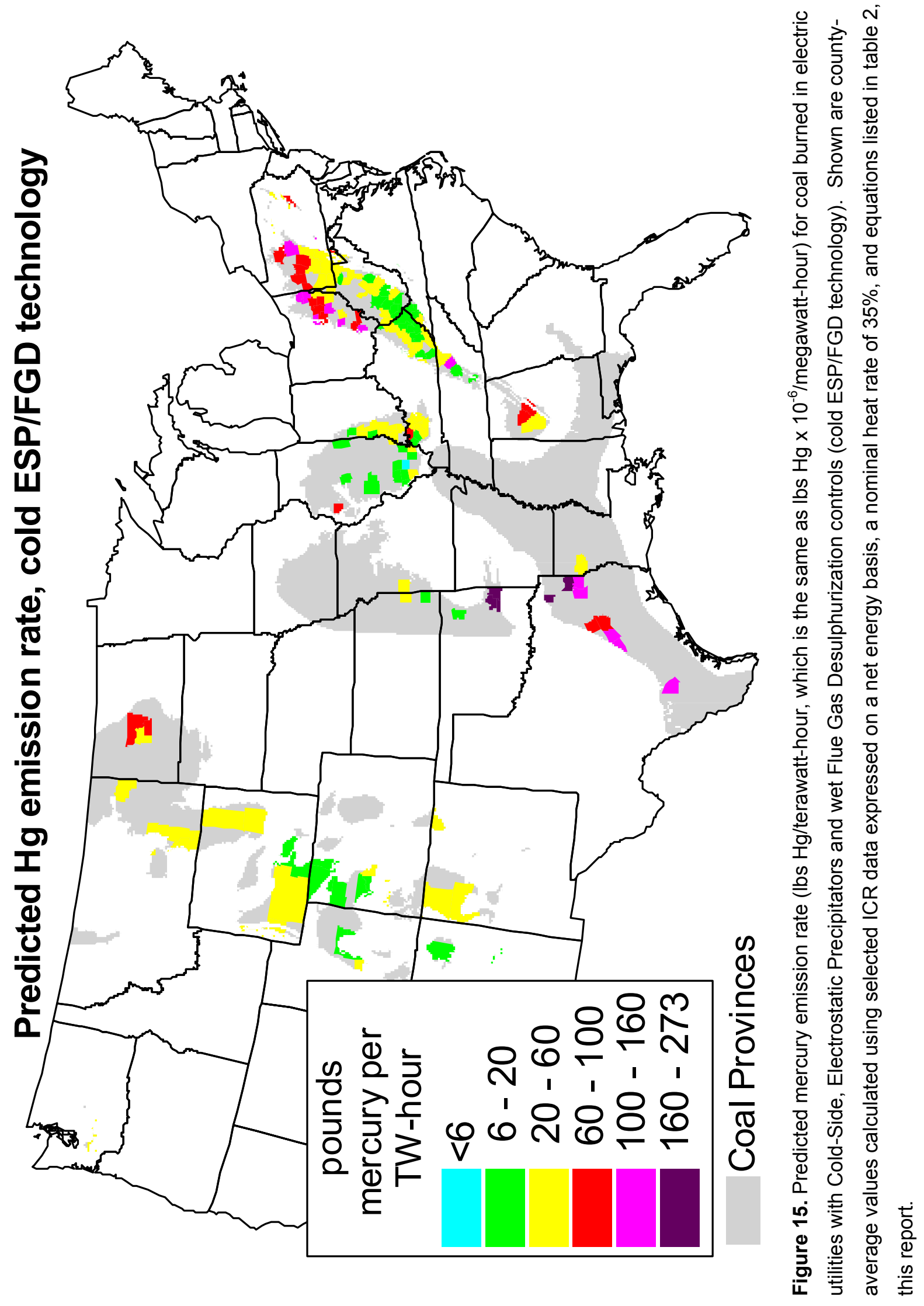




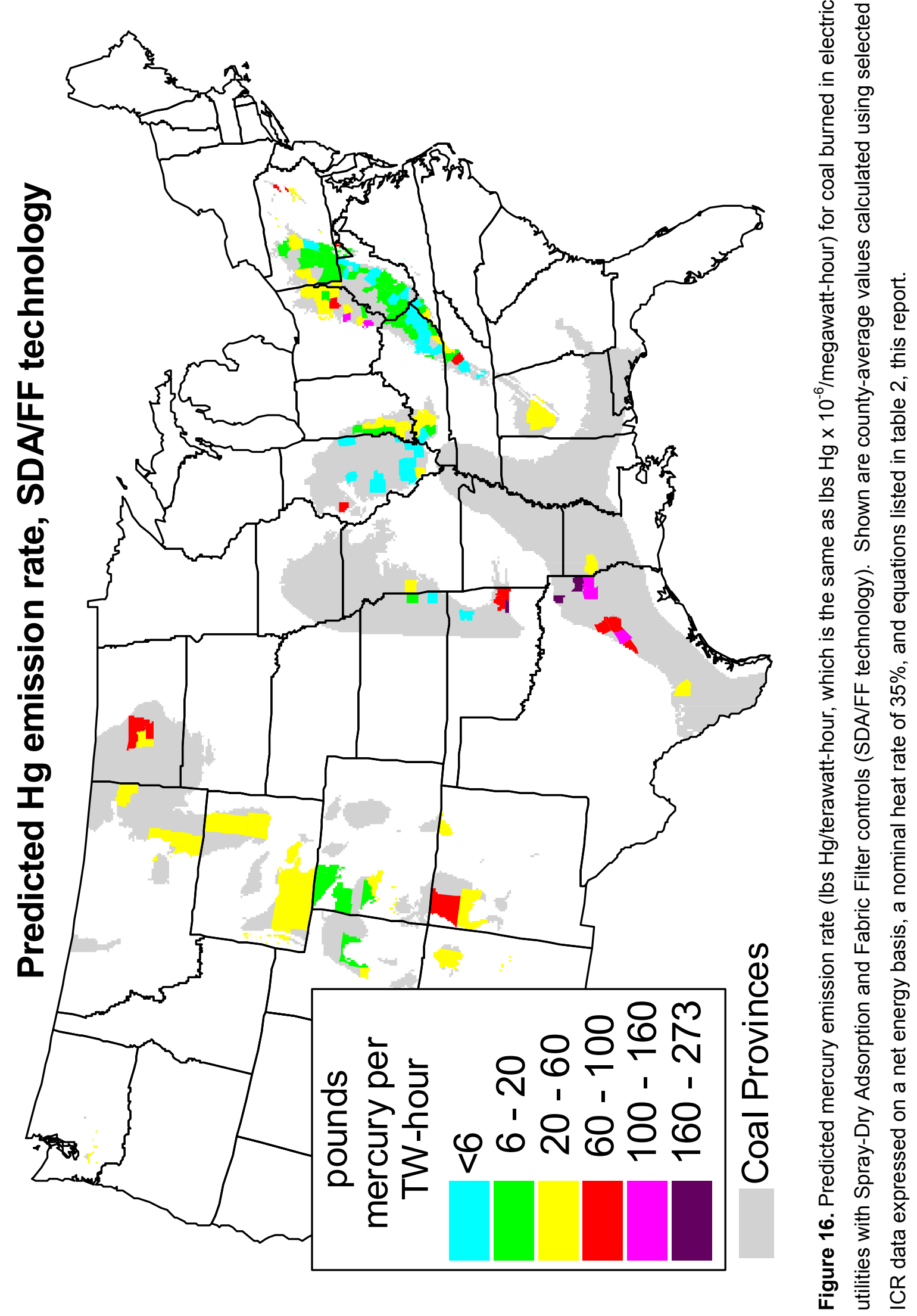




\section{RESULTS AND DISCUSSION}

Revised draft maps showing the potential mercury and acid-gas emissions from coal combustion by U.S. county-of-origin were made using selected ICR 2 coal quality data, and the average result from three, technology-specific equations that predict mercury capture (table 2).

This section discusses the decision to use the average result from three equations (rather than just one) as well as strategies to reduce mercury emissions using existing technology. We also examine the effectiveness of existing technologies to control mercury emissions, and consider why coal sulfur appears to reduce mercury capture. Finally, we examine the significance and potential of pre-combustion controls to reduce mercury emissions.

\section{Selecting the Best Equation to Predict Mercury Capture}

Table 2 lists three equations that predict mercury capture for each of five different existing control technologies. The equations were all derived by regression analysis on the ICR 3 stack emission data (USEPA, 2003), and use various measures of coal quality (chlorine, Btu, and sulfur values) as independent variables. Although the technology-specific equations show similar correlations and trends, results sometimes differ when they are applied to the same county-average coal quality values. Lacking objective criteria to select a single best equation from those listed in table 2, we used the average result obtained from all three equations.

Clearly, our decision to use all three equations, rather than just one, could be considered arbitrary. However, using three equations should reduce extrapolation error when an equation is applied to assay values that are outside the range of ICR 3 values that these regression equations were made from. For example, figure 6 shows that the different equations predict substantially different results for high-chlorine coal burned units with hESP technology. With one exception (Cliffside unit 1), relatively low-chlorine coal was burned in ICR 3 units equipped with this 
technology. Consequently, the validity of the hESP-specific equations is uncertain for highchlorine coal. Nonetheless, given the divergent results for high-chlorine coal shown in figure 6, using the average result from all three equations clearly avoids large errors necessarily associated with at least one of the equations.

Admittedly, there are other useful and significant equations that are not included in table 2 (Chu and others, 2000; Laumb and other 2000; AEMS 2004). However, the selection of equations for table 2 was not wholly arbitrary. The selection was instead a compromise that required similar technology classes, and favored high $\mathrm{r}^{2}$ values, diverse authorship, and different independent variables. Selecting three (rather than two, four, or more) equations for each technology group was likewise a compromise. This convention simplified spreadsheet calculations and allowed for the inclusion of convex, concave, and linear equation forms.

\section{Comparison of Existing Technologies: Implications for Mercury Control}

Figure 17 compares the average technology-specific mercury capture calculated for 162 U.S. counties using the three equations listed in table 2 for each technology control class. Note that mercury capture increases as coal chlorine increases for each control technology. This trend is particularly noteworthy for $\mathrm{SDA} / \mathrm{FF}$ and $\mathrm{cESP} / \mathrm{FGD}$ technologies, where capture rapidly

increases up to about $500 \mathrm{ppm}$ chlorine, but only modestly increases above $1000 \mathrm{ppm}$ chlorine. Thus, blending a low-chlorine coal with a high-chlorine coal to an optimum level between 500 and $1000 \mathrm{ppm}$ chlorine, should result in a net reduction of mercury emissions for coal burned in units equipped with SDA/FF or cESP/FGD emission controls. 


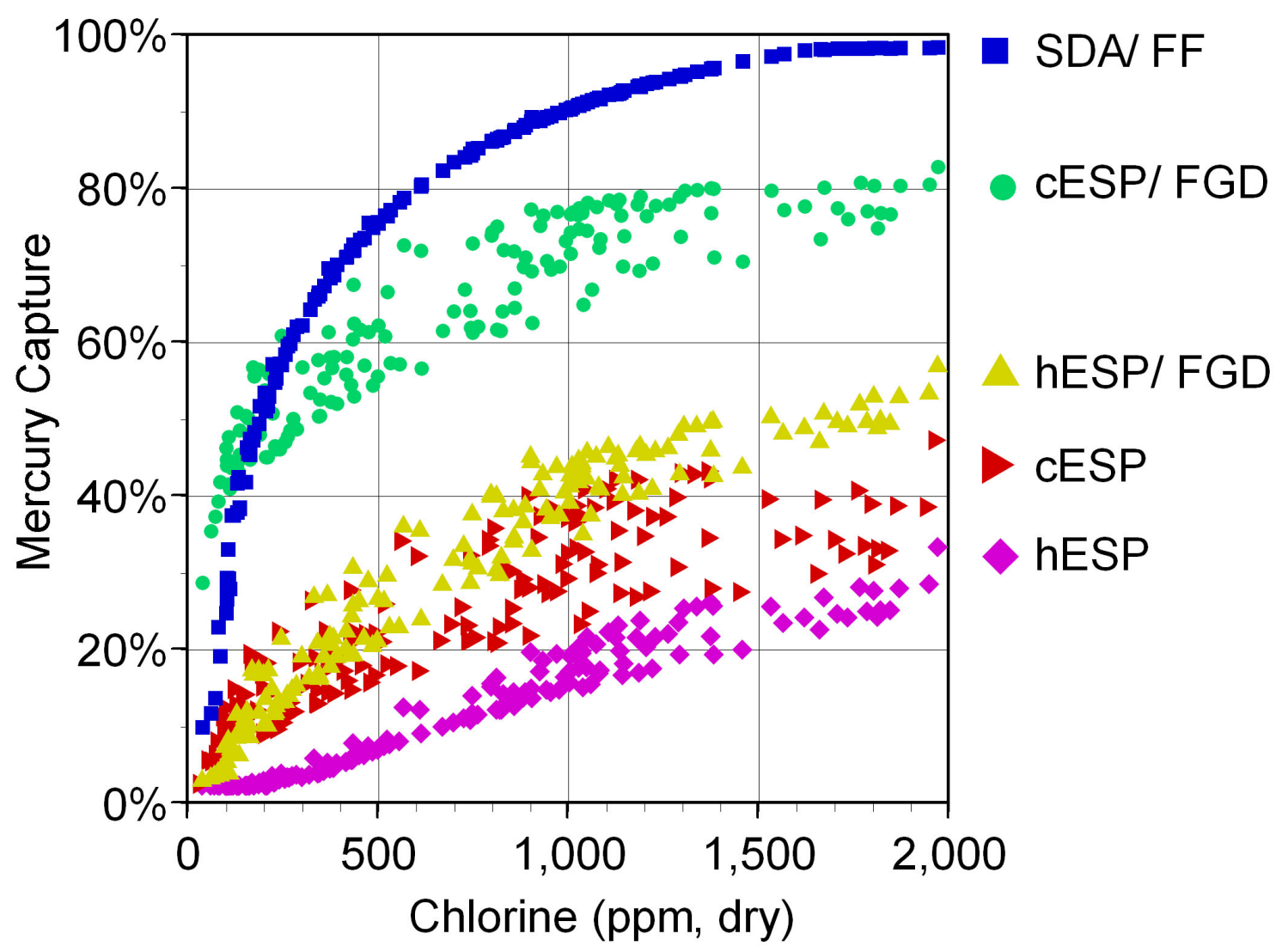

Figure 17. Mercury capture predicted for 162 U.S. counties increases with increasing coal chlorine for five existing control technologies. Mercury capture is the average result of three equations for each control technology applied to county-average, ICR 2 coal assay values. The equations are listed in table 2 (this report); county-average ICR 2 assay values are listed the appendix.

Units equipped with hESP/FGD, cESP/FGD or hESP emission controls show relatively poor mercury capture. Absent effective mercury-specific controls, selection of low-mercury coal would be a good mercury control strategy for these units.

Weighting the county-specific results shown in figure 17 by county production tonnage allows calculation of the average mercury emissions, together with the average percent reduction, for each post-combustion technology. Likewise, the effectiveness of pre-combustion technology can be calculated by comparing in-ground coal mercury with commercially shipped 
coal mercury and weighting the results by county production. Table 3 shows the results of these calculations.

Table 3. Comparison of mercury control technologies, by U.S. county-of-origin.

\begin{tabular}{|c|c|c|c|c|}
\hline & $\underline{\text { Technology }}$ & $\underline{\text { Trillion Btu }}^{1}$ & $\underline{\mathrm{lbs} \mathrm{Hg} / 10^{12} \mathrm{Btu}}$ & $\begin{array}{l}\% \text { Mercury } \\
\text { Reduction }\end{array}$ \\
\hline \multirow{4}{*}{$\begin{array}{l}\text { Pre- } \\
\text { Combustion }\end{array}$} & $\begin{array}{l}\text { None (In-ground coal, } \\
\text { COALQUAL data) }\end{array}$ & - & $\sim 11.0$ & - \\
\hline & $\begin{array}{l}\text { Counties with no mercury } \\
\text { reduction (ICR } 2 \text { data) }\end{array}$ & 5,931 & 11.2 & - \\
\hline & 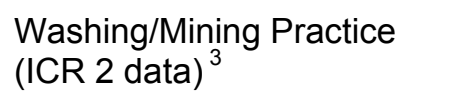 & 11,335 & 6.3 & $\sim 57 \%$ \\
\hline & $\begin{array}{l}\text { No data (counties without } \\
\text { COALQUAL or ICR } 2 \text { data) }\end{array}$ & 1,809 & $?$ & $?$ \\
\hline \multirow{6}{*}{$\begin{array}{l}\text { Post- } \\
\text { Combustion }\end{array}$} & None (delivered coal) & 19,047 & 8.3 & - \\
\hline & hESP & 1,769 & 7.5 & $9 \%$ \\
\hline & cESP & 10,260 & 6.3 & $24 \%$ \\
\hline & hESP/FGD & 565 & 6.2 & $25 \%$ \\
\hline & cESP/FGD & 3,579 & 3.4 & $59 \%$ \\
\hline & SDA/FF & 511 & 3.1 & $63 \%$ \\
\hline
\end{tabular}

${ }^{1}$ Amount of coal, expressed as coal Btu content; post-combustion values from Chu and others (2000).

2 The $11 \mathrm{lb} \mathrm{Hg} / 10^{12}$ Btu value for the total U.S. in-ground coal resource was calculated using stateaverage COALQUAL Hg values, and weighting by estimated coal resource (tonnage) values from the USEIA (2000) 1997 vintage, demonstrated reserve base. This value (and the derived $57 \%$ mercury reduction due to washing and mining practice) will likely change when the demonstrated reserve base estimate is updated.

${ }^{3}$ Counties where the mercury content of the in-ground coal is more than $2 \mathrm{lbs} \mathrm{Hg} / 10^{12}$ Btu greater than the mercury content of commercial coal shipped from that county.

Several caveats apply to table 3 . First, mercury reductions listed for cESP/FGD and SDA/FF technologies are likely minimum values because they indicate the fractional emissions expected if all U.S. coal were burned in these technology classes, rather than the coals that are currently burned. Many of these units burn coal blends originating from several counties. As 
noted above, the optimal mercury capture for these technologies occurs where the coal contains between 500 and 1000 ppm chlorine. Given that the tonnage-weighted average chlorine content of U.S. coal is $\sim 530 \mathrm{ppm}$, coal blends are more likely to approach this optimal value than singlesourced coal.

Table 3 shows that in-ground U.S. coal contains about $11 \mathrm{lbs} \mathrm{Hg} / 10^{12} \mathrm{Btu}$. This value is less certain than the mercury content of coal delivered to power plants during 1999 included in the ICR 2 data set. For example, weighting COALQUAL mercury values aggregated by U.S. state (excluding Alaska), by the USEIA (2000) Demonstrated Reserve Base tonnage estimates for these states shows an average $10.8 \mathrm{lbs} \mathrm{Hg} / 1012 \mathrm{Btu}$. However, where average COALQUAL mercury values for counties listed in the ICR data set are weighted by coal production tonnage, the result is $11 \mathrm{lbs} \mathrm{Hg} / 10^{12} \mathrm{Btu}$.

Another limitation of values listed in table 3 relates to the likely co-reduction of coal sulfur due to coal mining and coal washing practice. As noted below, coal sulfur decreases postcombustion mercury capture. Consequently, the technology-specific, post-combustion mercury reductions listed in table 3 may increase if the sulfur content of commercial U.S. coal continues to decline (Quick and others, 2004).

\section{The Relationship Between Coal Sulfur and Mercury Capture}

Figure 17 shows that mercury emissions from SDA/FF controls are exclusively correlated with chlorine whereas mercury emissions predicted for the other technologies are more variable. The scatter shown in figure 17 for cESP/FGD, hESP/FGD, cESP, and hESP technologies is attributed to coal sulfur, which is a factor in one or more of the respective equations for these technologies (table 2), but not used in the SDA/FF equations. Notably, in every equation where 
sulfur is an independent variable (table 2), mercury capture is predicted to decline with increasing coal sulfur.

The equations listed in table 2 clearly show the consistently negative effect of coal sulfur on mercury capture. The explanation for this effect is less obvious. Hocquel and others (2001) offer two explanations for the negative effect of sulfur on mercury capture; both reduce the amount of $\mathrm{Cl}_{2}$ available for mercury oxidation. The first inhibits the heterogeneous conversion of $\mathrm{HCl}$ to reactive $\mathrm{Cl}_{2}$ by sulfation of metal oxides that would otherwise catalyze this conversion. The second indicates that gaseous $\mathrm{SO}_{2}$ in the presence of water vapor can homogenously reduce $\mathrm{Cl}_{2}$ to less-reactive $\mathrm{HCl}$ and by-product $\mathrm{SO}_{3}$. A mechanistic model for mercury capture by flyash carbon (Olson and others 2003) suggests that sulfuric acid (from oxidation of flue-gas $\mathrm{SO}_{2}$ ) limits mercury capture by filling Hg binding/reaction sites on the carbon surface.

Alternately, the negative effect of coal sulfur on mercury capture may simply relate to higher flue-gas temperatures required to avoid corrosion of the ductwork from $\mathrm{H}_{2} \mathrm{SO}_{4}$ when burning high-sulfur coal. Meij and others (2002) attribute the greater mercury capture by ESP controls on power plants in the Netherlands, compared to those in Germany and the U.S., to lower flue-gas ESP temperatures in the Netherlands power plants $\left(\sim 120^{\circ} \mathrm{C}\right)$, which burn comparatively low-sulfur coal. The median temperature for cold-side ESP units included in the ICR 3 data set of U.S. power plants is about $160^{\circ} \mathrm{C}$, whereas Meij and others (2002) suggest that oxidized mercury, present as $\mathrm{HgCl}_{2}$, does not condense on fly ash above about $140{ }^{\circ} \mathrm{C}$.

Empirical data from Canadian Electricity Association members (CEA, 2004) also show a negative correlation between coal sulfur on mercury capture. The relationship (figure 18) is strongest where fly-ash carbon exceeds five percent (and chlorine is coincidentally high). This relationship is consistent with the mechanistic model suggested by Olson and others (2003) 
where sulfur fills reactive sites on fly-ash carbon. Their explanation may also explain why sulfur is not a significant predictor of mercury capture for units equipped with SDA/FF technology; in this instance, gaseous flue-gas sulfur is converted to a non-reactive solid (sulfate) before it arrives at the particulate filter, where effective mercury capture by fly-ash carbon presumably occurs.

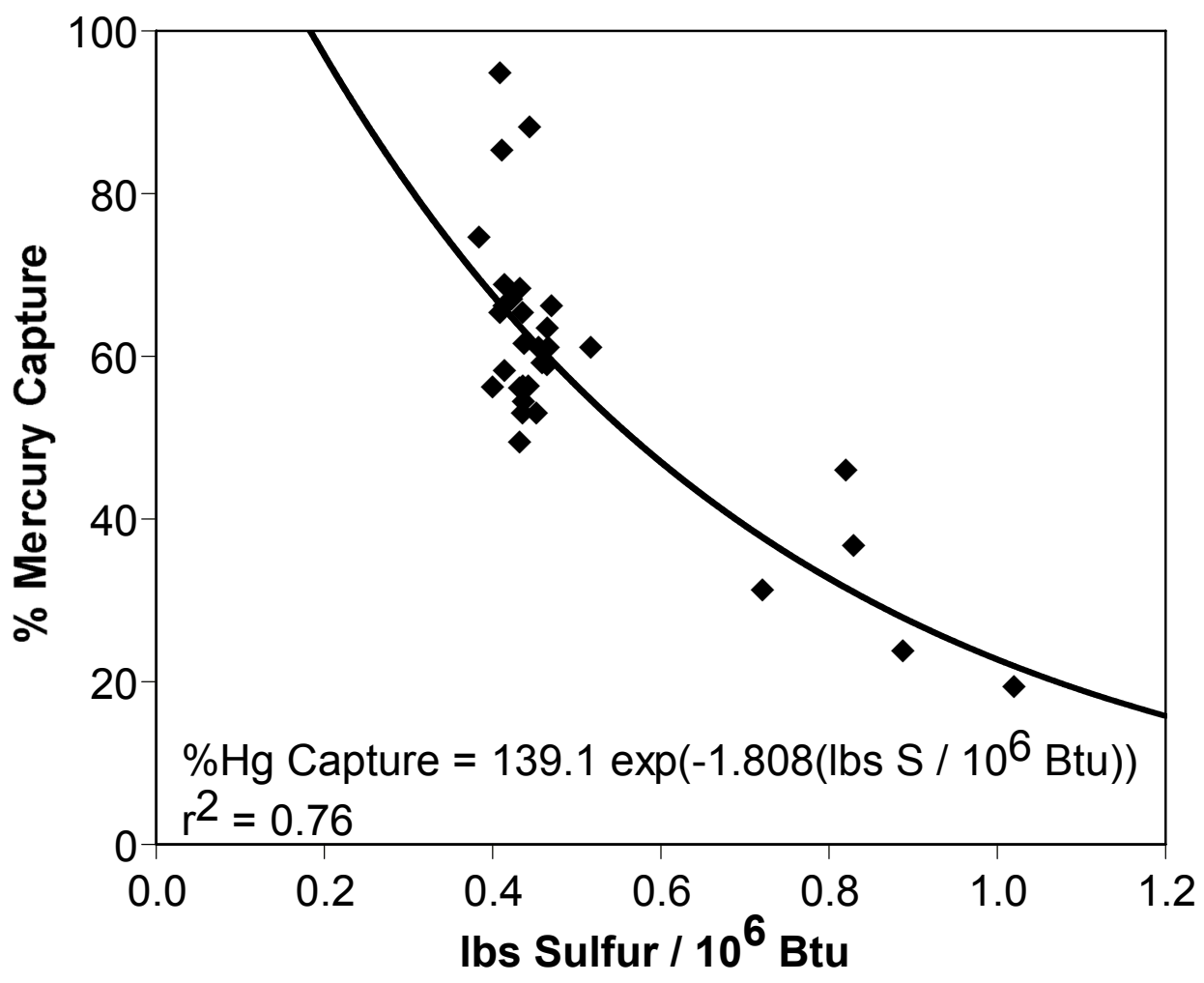

Figure 18. Decreasing mercury capture with increasing coal sulfur. Data points show weekly averages (CEA, 2004) observed for two units equipped with cESP emission controls where fly-ash carbon exceeds $5 \%$ (average 11\%). Mercury capture was estimated after Meij and others (2002) using coal and fly-ash mercury values, and assuming an 80:20, fly ash:bottom ash fractionation. Two data points greater than $100 \%$ capture are not shown.

In this section we have suggested that mercury capture by carbon in fly ash may be improved by reducing the amount of sulfur in the feed coal. This effect complements the likely reduction of mercury in the coal when the sulfur content of coal is reduced (Quick and others, 
2003). Thus, selection of low-sulfur coal has two likely effects: (1) reducing the amount of mercury in the feed coal, and (2) improving post-combustion mercury capture.

\section{In-Ground Coal Mercury Compared to Commercial Coal Mercury}

Direct comparison of COALQUAL data records (in-ground coal) with ICR 2 data records (commercial coal) showed that coal delivered to utilities during 1999 has about half as much mercury as the in-ground coal resource (Quick and others, 2003). This difference was attributed to preferential mining of relatively low-mercury coal, and coal washing. Toole-O'Neil and others (1999) note that washing reduces coal mercury levels by about 35\%. Restricting the comparison to counties where both COALQUAL and ICR data are available, and weighting the county-average mercury values by coal production tonnage, shows that the in-ground coal resource averages about $11 \mathrm{lbs} \mathrm{Hg} / 10^{12} \mathrm{Btu}$, whereas commercial coal deliveries during 1999 averaged about $8.3 \mathrm{lbs} \mathrm{Hg} / 10^{12} \mathrm{Btu}$. Perhaps more significantly, this difference is not geographically uniform. For example, figure 19 shows that coal produced from the northern Appalachians and Gulf Coast regions typically has more mercury than expected from the mercury content of the in-ground coal. The reason for these increased mercury levels is uncertain. Possibly, the increased mercury levels result from dilution of mined coal with either surrounding, high-mercury country rock or included, high-mercury rock partings. If so, coal washing or selective mining might be effective mercury reduction strategies in these areas. 


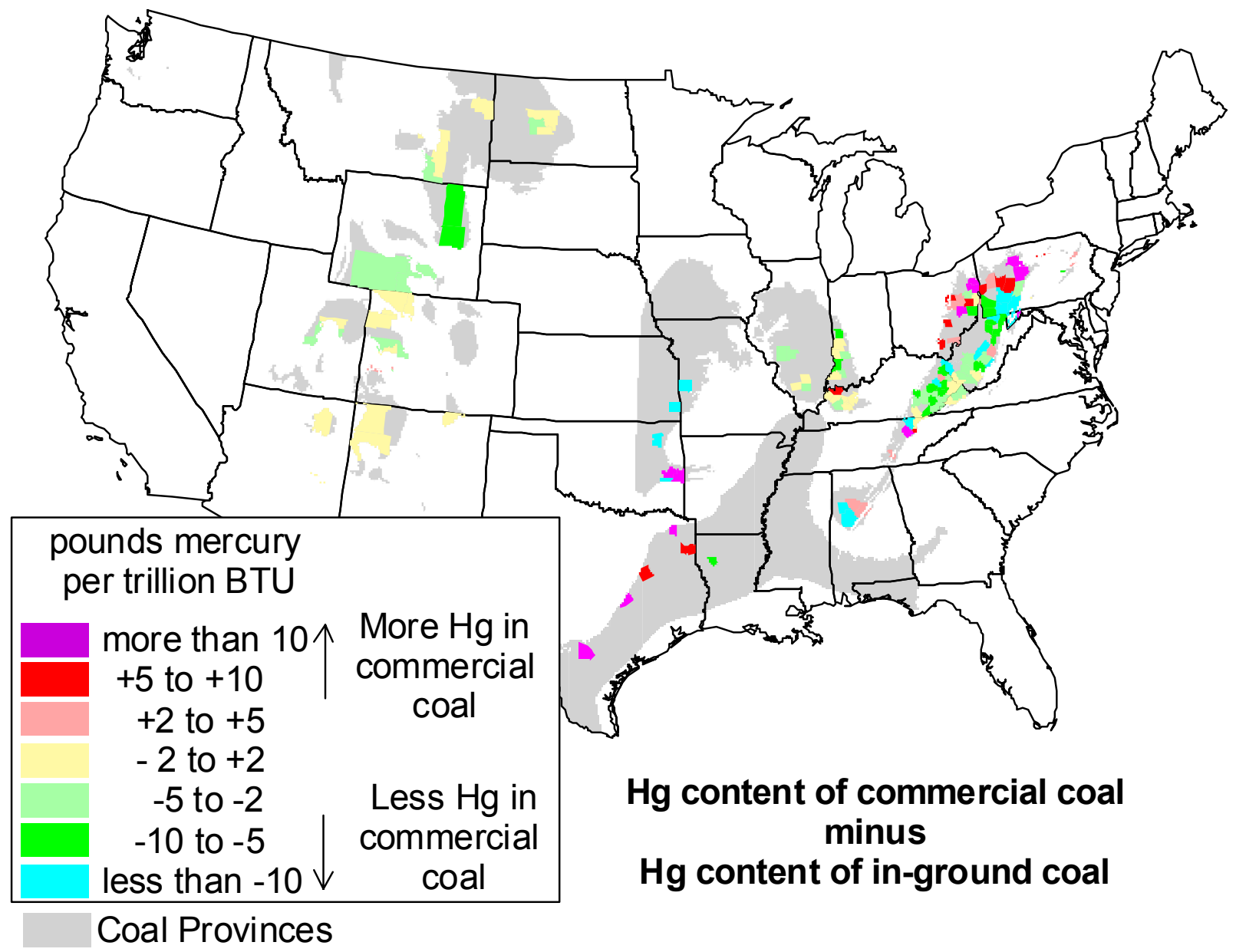

Figure 19. Commercial coal from some areas has more mercury than what might be expected based on in-ground coal assays (COALQUAL data). Although the mercury content of commercial coal delivered to utilities during 1999 (ICR 2 data) was about 25\% less than the actively mined, in-ground coal resource (COALQUAL data), this difference is not geographically consistent.

Areas where mined coal contains more mercury than the in-ground coal may be good places to consider pre-combustion mercury reduction strategies. Comparing the mercury content of mined coal with the mercury content of in-ground coal has more immediate significance because it shows the significance of pre-combustion mercury reduction strategies (selective mining and coal washing). Indeed, the mercury content of U.S. coal delivered to the power plant 
during 1999 contained, on average, $2.8 \mathrm{lbs} \mathrm{Hg} / 10^{12}$ Btu less mercury than the in-ground coal resource. This $25 \%$ mercury reduction is significant.

\section{CONCLUSIONS}

We have revised draft maps showing potential sulfur, chlorine, and mercury emissions for U.S. coals by county-of origin, and have begun construction of the final maps. Although county-average ICR 2 mercury values for most Gulf Coast coal have been increased (in recognition of systematic assay errors), mercury values for Leon County Texas, as well as DeSoto and Red River Parishes Louisiana, have not been adjusted and are probably too low. Results from this reporting period suggest the following:

- Selection of coal with low mercury content may be an effective control strategy for units equipped with hESP/FGD, cESP, or hESP controls, whereas selection of highchlorine coal is indicated for units with cESP/FGD or SDA/FF controls.

- Blending to an optimum level between 500 and 1000 ppm chlorine may be an effective mercury control strategy for units equipped with SDA/FF or cESP/FGD controls.

- Flue-gas sulfur may reduce mercury capture by carbon in fly ash.

- Coal washing or selective mining might be an effective mercury reduction strategy, especially for coals from the northern Appalachians or Gulf Coast.

\section{REFERENCES}

AEMS, LLC, 2004, Review and critique of data and methodologies used in the USEPA proposed utility mercury MACT rulemaking, report prepared for the National Mining Association: 
AEMS, LLC, Arlington Virginia, and RWCrawford Energy, Tuscon Arizona, 88 p., Online, <nma.org/pdf/pol_briefs/mact_critique_072004.pdf>, accessed July 2004.

Anonymous, 1990, The Penn State Coal Sample Bank and Data Base, second edition: Coal and Organic Petrology Laboratories, University Park, Pennsylvania, The Pennsylvania State University, unpaginated data sheets.

Bragg, L.J., Oman, J.K., Tewalt, S.J., Oman, C.L., Rega, N.H., Washington, P.M., and Finkelman R.B., 1997, Coal quality (COALQUAL) database - version 2.0: U.S. Geological Survey Open-File Report 97-134, CD-ROM.

Canadian Electricity Association, 2004, Mercury program, sampling and analysis, participant data (preliminary): Online, <ceamercuryprogram.ca/EN/sampling_data.html $>$, accessed October 2004.

Chu, P., Goodman, N., Behrens, G., and Roberson, R., 2000, Total and speciated mercury emissions from coal-fired power plants: Palo Alto, California, Electric Power Research Institute, 15 p., Online, <epri.com/attachments/262300_EUEC_pchu_1-01.pdf $>$, accessed July 2004.

Davis, A., and Glick, D.C., 1993, Establishment and maintenance of a coal sample bank and data base, final report to the U.S. Department of Energy for contract DE-RP22-87PC79997: University Park, The Pennsylvania State University, Coal and Organic Petrology Laboratories, $266 \mathrm{p}$.

ENSR Corporation, 2003, Multivariable method to estimate the mercury emissions of the bestperforming coal-fired utility units under the most adverse circumstances which can reasonably be expected to recur; report DC $\$ 566987.6$ prepared for WEST Asscociates, Tucson, Arizona, and present at the March 4, 2003 meeting of the Clean Air Act Advisory Committee Permits/New Source Review/Air Toxics Subcommittee Utility MACT Working Group: 45 p., Online, <epa.gov/ttn/atw/combust/utiltox/final_ensr_multivar.pdf>, accessed July 2004.

Eutizi, J.G., 2005, Comment from San Miguel Electric Cooperative to EPA Docket OAR-20020056, in response to the Notice Of Data Availability for the proposed clean air mercury 
rule, 69 FR 69864, Dec. 1, 2004: Online, <docket.epa.gov/edkpub/index.jsp>, Accessed January 2005, OAR-2002-0056-3463, 3p.

Glacken, S., 2005, Comment from TXU Power to EPA Docket OAR-2002-0056, in response to the Notice Of Data Availability for the proposed clean air mercury rule, 69 FR 69864, Dec. 1, 2004: Online, <docket.epa.gov/edkpub/index.jsp>, Accessed January 2005, OAR-2002-0056-5490, 2p.

Hocquel, M., Unterberger, S., and Hein, K.R.G., 2001, Influence of $\mathrm{HCl}, \mathrm{SO}_{2}, \mathrm{CaO}$ and catalytic material on the speciation of mercury: Proceedings of the Air and Waste Management Association Specialty Conference on Mercury Emissions, Fate, Effects, and Control, August 21-23, Chicago, Illinois, 11p.

Laumb, J., Jensen, R., and Benson, S., 2000, Information Collection Request (ICR) for mercury - correlation analysis of coal and power plant data: Proceedings of the Air Quality II Mercury, Trace Elements, and Particulate Matter Conference, McLean Virginia, Sept. 1921, poster paper 15 .

McCall, M., 2004, Comment from TXU Power to EPA Docket OAR-2002-0056, in response to the proposed mercury rule 69 FR 4652, Jan. 30, 2004: Online, $<$ docket.epa.gov/edkpub/index.jsp>, Accessed January 2005, OAR-2002-0056-3478, $37 \mathrm{p}$.

Meij, R., Vredenbregt, L.H.J., and Winkel, H., 2002, The fate and behavior of mercury in coalfired power plants: J. Air Waste Manage. Assoc., v. 52, p. 912-917.

Olson, E.S., Laumb, J.D., Benson, S.A., Dunham, G.E., Sharma, R.K., Mibeck, B.A., Crocker, C.R., Miller, S.J., Holmes, M.J., and Pavlish, J.H., 2003, The mechanistic model for flue gas-mercury interactions on activated carbons: Proceeding of the Air Quality IV Mercury Trace Elements and Particulate Matter Conference, September 22-24, Arlington Virginia, $9 \mathrm{p}$.

Quick, J.C., Brill, T.C., and Tabet, D.E., 2003, Mercury in US coal - observations using the COALQUAL and ICR data: Environmental Geology, v. 43, p. 247-259.

Quick, J.C., Tabet, D.E., Wakefield S., and Bon, R.L., 2004a, Optimizing technology to reduce mercury and acid gas emissions from electric power plants, semi-annual report, August 
2003 to January 2004, for U. S. Department of Energy contract DE-FG26-03NT41901: Salt Lake City, Utah Geological Survey, 49 p.

Quick, J.C., Tabet, D.E., Wakefield S., and Bon, R.L., 2004b, Optimizing technology to reduce mercury and acid gas emissions from electric power plants, semi-annual report, February 2004 to July 2004, for U. S. Department of Energy contract DE-FG26-03NT41901: Salt Lake City, Utah Geological Survey, XX p.

Quick, J.C., Tabet, D.E., Wakefield S., Bon, R.L., and Brill, T., 2005, Geographic variation of mercury content, and mercury emissions predicted for existing technologies, by U.S. county of coal origin: Presentation for the $8^{\text {th }}$ Electric Utilities Environmental Conference on Air Quality, Global Climate Change, and Renewable Energy, January 2426, Tucson, Arizona, Online, <http://geology.utah.gov/emp/mercury/index.htm >, accessed February, 2005.

Roberson, R., 2002, UARG variability analysis, memorandum to Bob Wayland, U.S. Environmental Protection Agency, presented at the October 17, 2002 meeting of the Clean Air Act Advisory Committee Permits/New Source Review/Air Toxics Subcommittee Utility MACT Working Group: Raleigh, North Carolina, RMB Consulting and Research, 4 p., Online, <epa.gov/ttn/atw/combust/utiltox/epavarifnl.doc $>$, accessed July 2004.

Scaroni, A.W., Davis, A., Glick, D.C., Hatcher, P.G., Mitchell, G.D., Carson, D., and Lei, H., 1999, Maintenance of the coal sample bank and data base; final technical report for the U.S. Department of Energy contract DE-AC22-93PC93051: University Park, The Pennsylvania State University, Coal and Organic Petrology Laboratories, 192 p.

Science Applications International Corporation, 2003, Calculation of possible mercury MACT floor values for coal-fired utilities - influence of variability and approach; report for the U.S. Department of Energy: Reston, Virginia, SAIC Corp., 46 p., 8 appendices, Online, $<$ netl.doe.gov/coal/E\&WR/mercury/pubs/DOE_Report_v120803.pdf >, accessed August 2004.

Toole-O'Neil, B., Tewalt, S.J., Finkelman, R.B., and Akers, D.J., 1999, Mercury in coal unraveling the puzzle: Fuel, v.78, p.47-54. 
U.S. Energy Information Administration, 2000, Coal Industry Annual 2000 (see table 33): DOE/EIA-0584, Online, <tonto.eia.doe.gov/FTPROOT/coal/05842000.pdf), accessed January 2005, 311p.

-2003a, FERC Form 423 Database, Monthly cost and quality of fuels for electric power plants: Online, <eia.doe.gov/cneaf/electricity/page/ferc423.html>, accessed October and November 2003.

-2003b, The Coal Transportation Rate Database data tables: Online, $<$ eia.doe.gov/cneaf/coal/ctrdb/database.html>, accessed October and November 2003.

U.S. Environmental Protection Agency, 2003, Unified air toxics website, electric utility steam generating units hazardous air pollutant emission study: Online, <epa.gov/ttn/atw/combust/utiltox/utoxpg.html>, accessed October and November 2003.

U.S. Mine Safety and Health Administration, 2004, Accident, Illness and Injury and Employment Self-Extracting Files (PART 50 DATA) Master Index File: Online, $<$ http://www.msha.gov/STATS/PART50/P50Y2K/Y2KMIF.HTM>, accessed November 2004. 


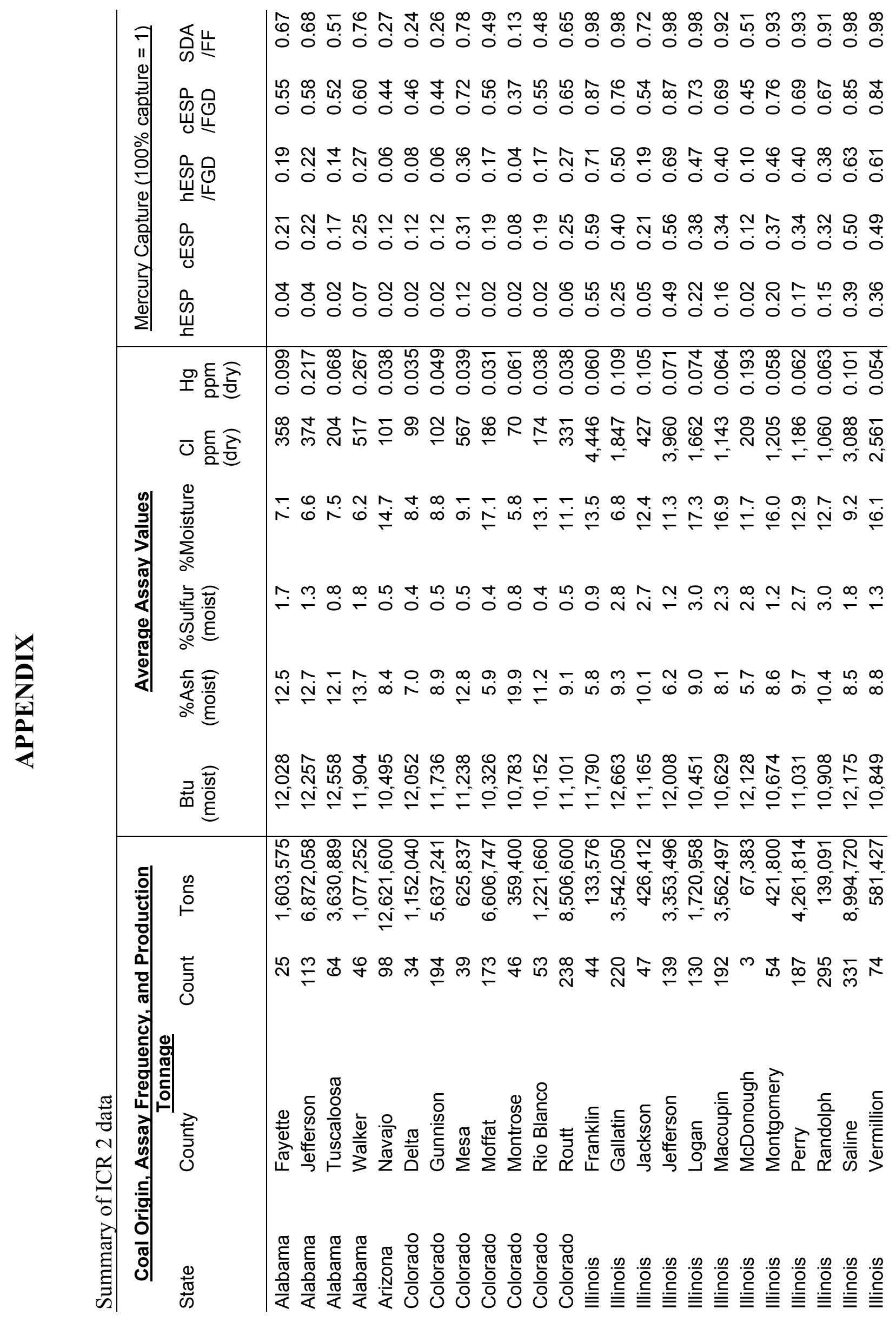


の ஊ

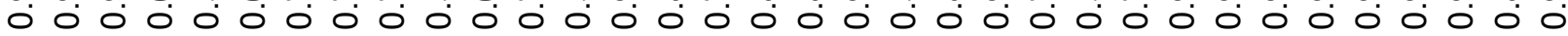

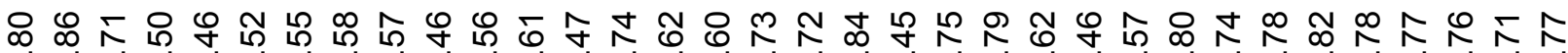

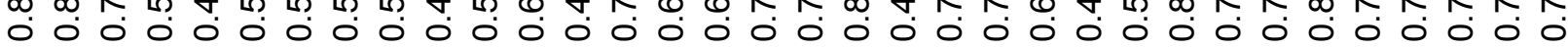

חִ

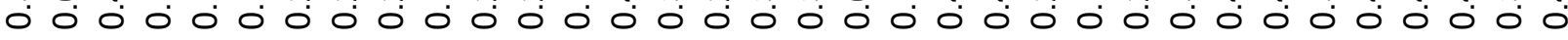

政

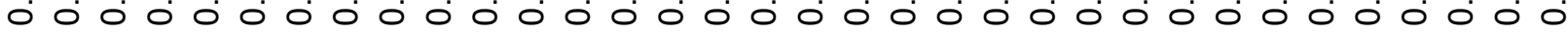

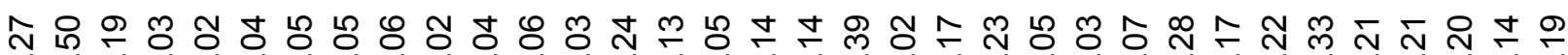

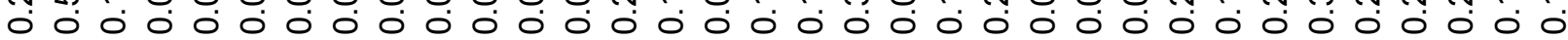

ป는 б.

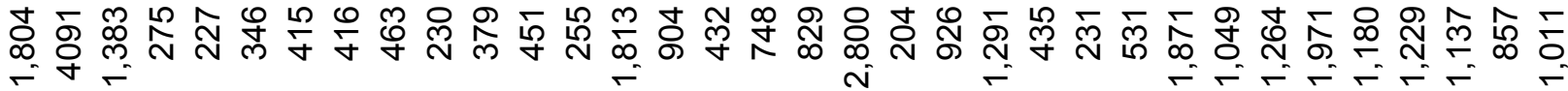
オ 0 . m드음

n

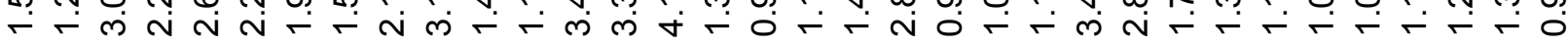

L

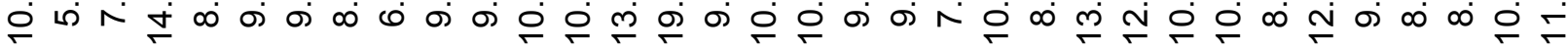

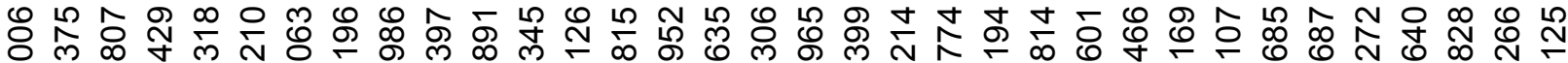

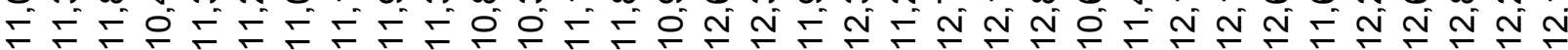

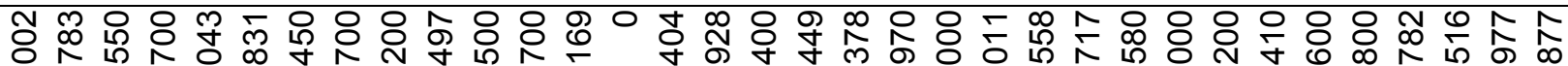
オี స

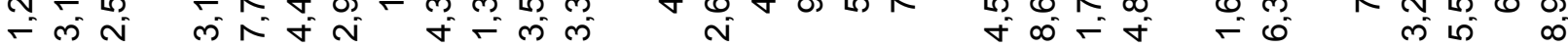
娈の

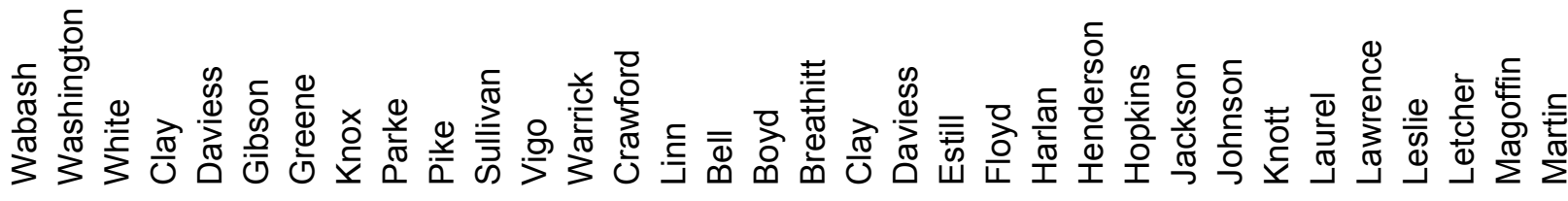

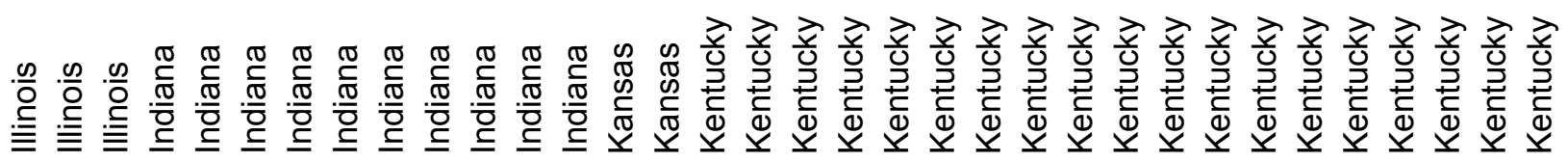




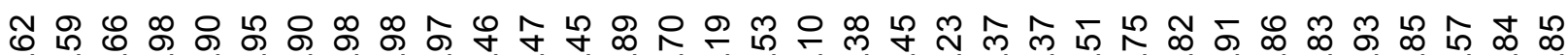

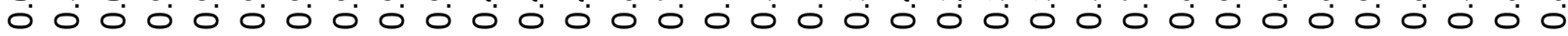

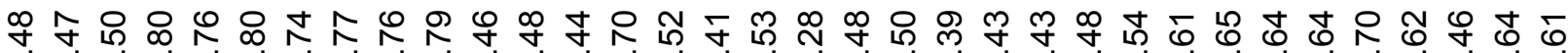

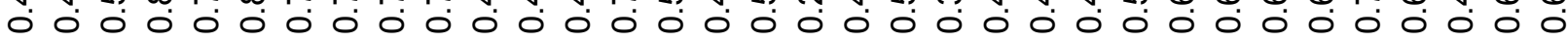

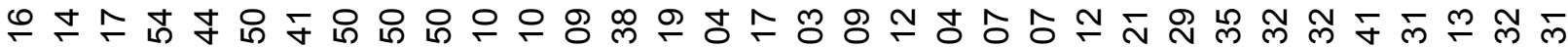

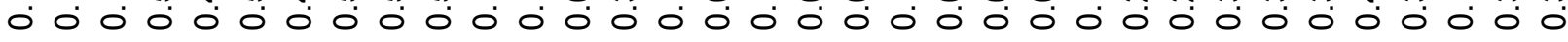

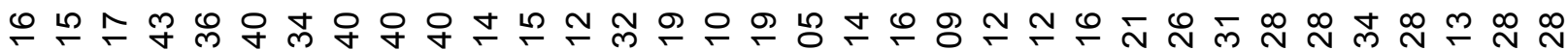

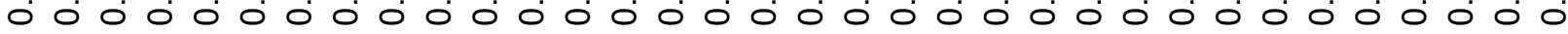

กำ

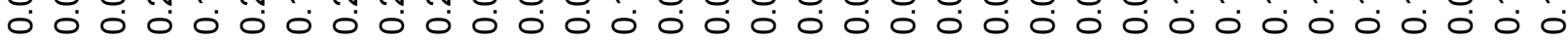

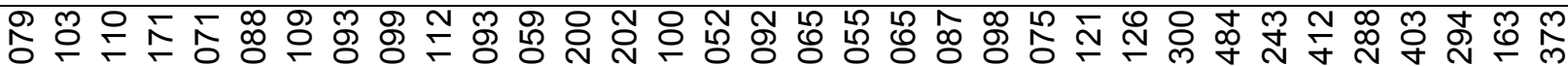
○

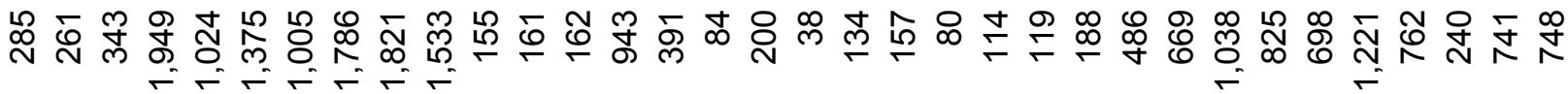

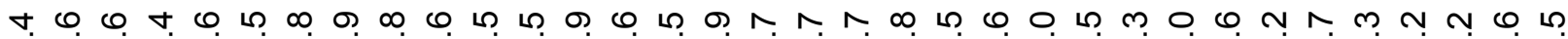

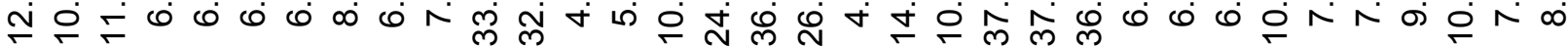

m บ m

人 ம்

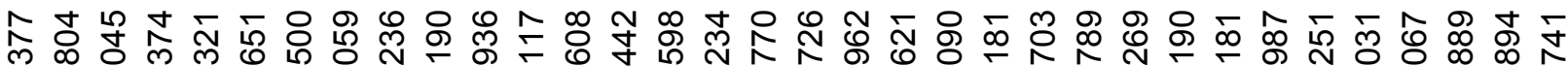

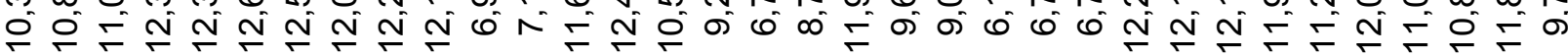

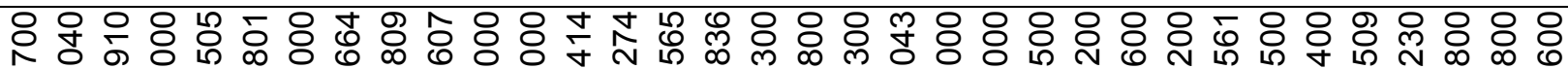

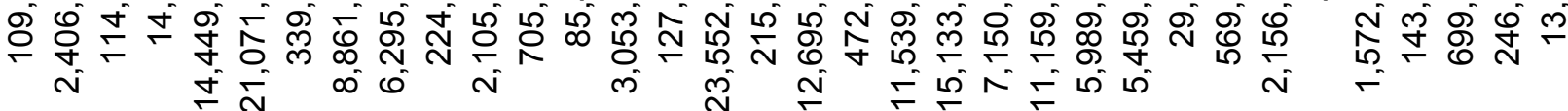

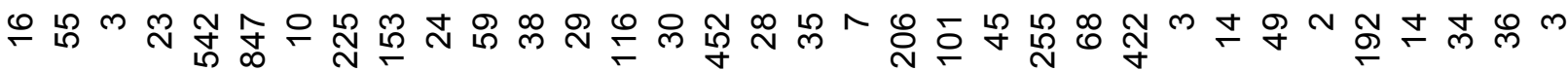
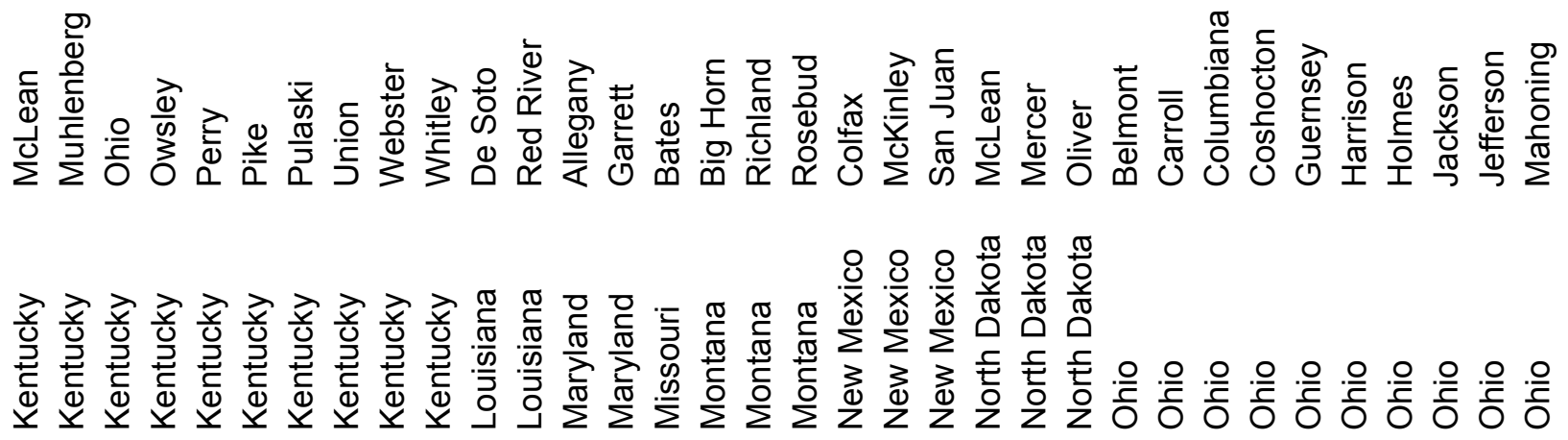
๑ வ

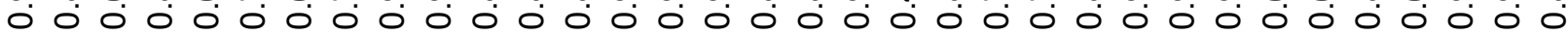

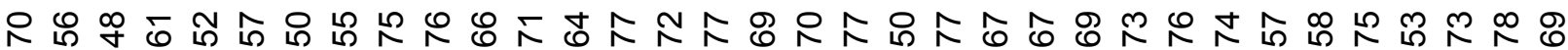

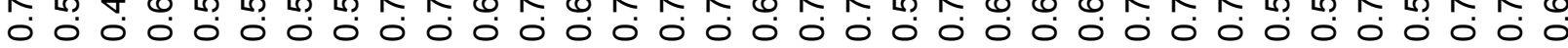

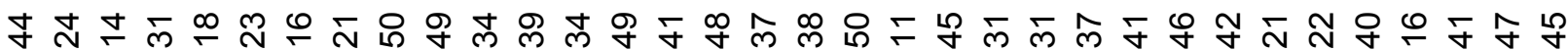

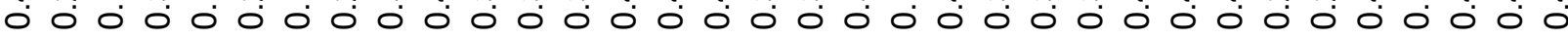

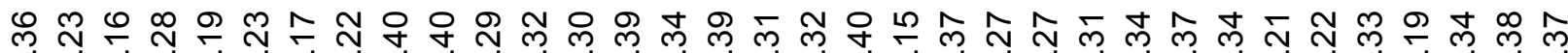

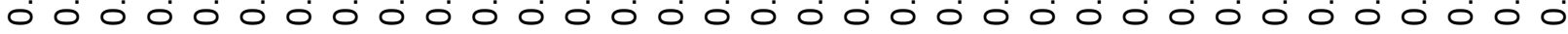

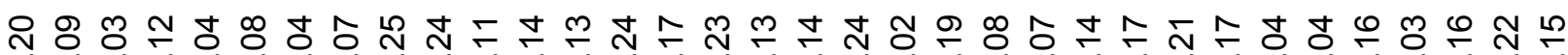

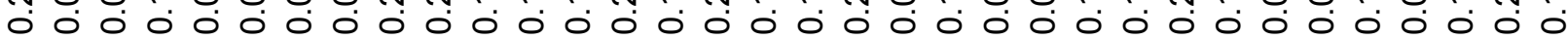

월 సั

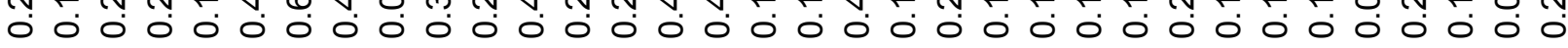
郘 $\infty \Upsilon$ \

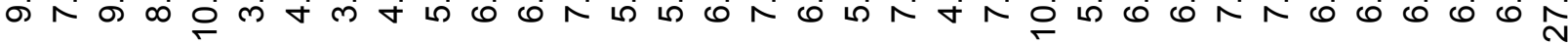

๑

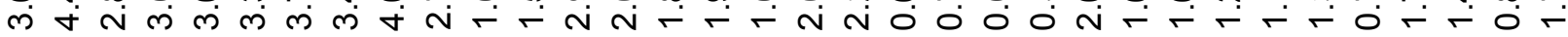

n 뜯ำ

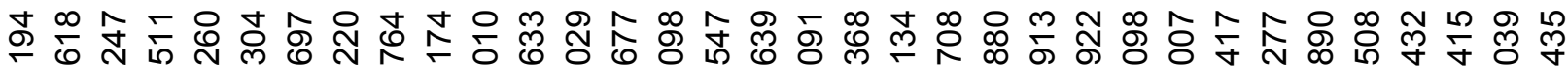

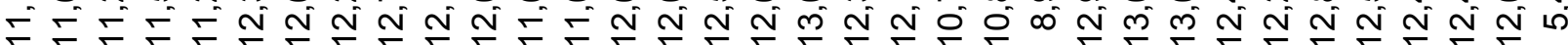

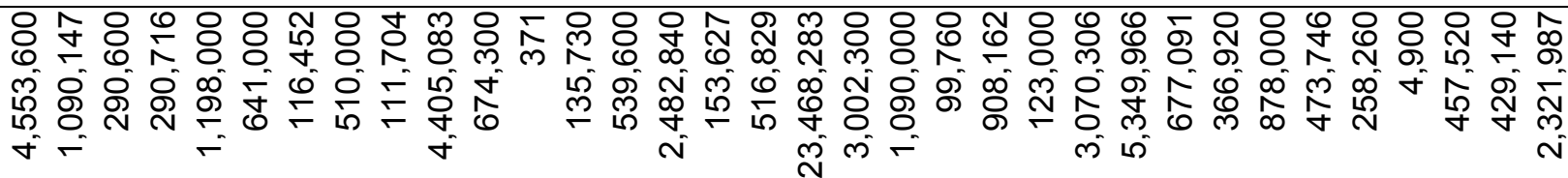

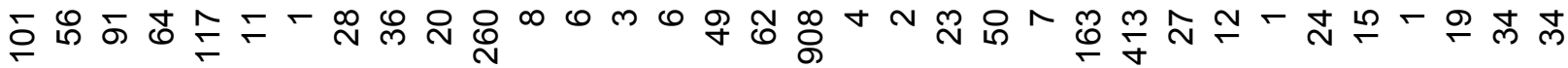

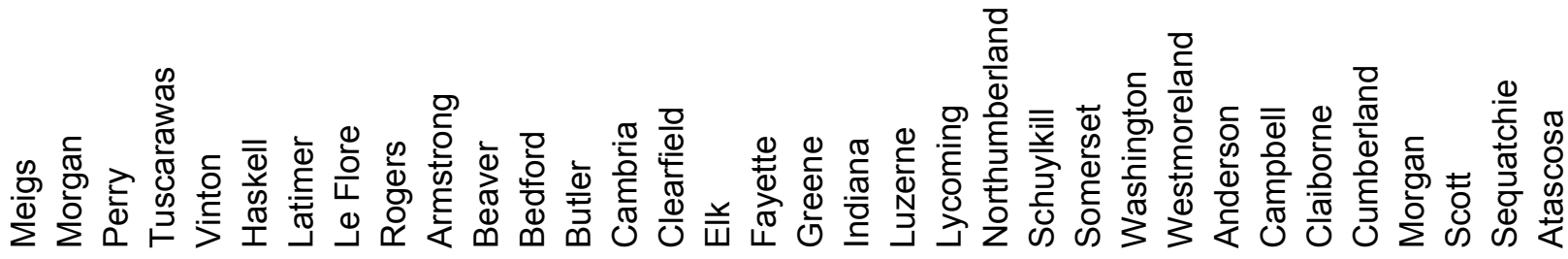

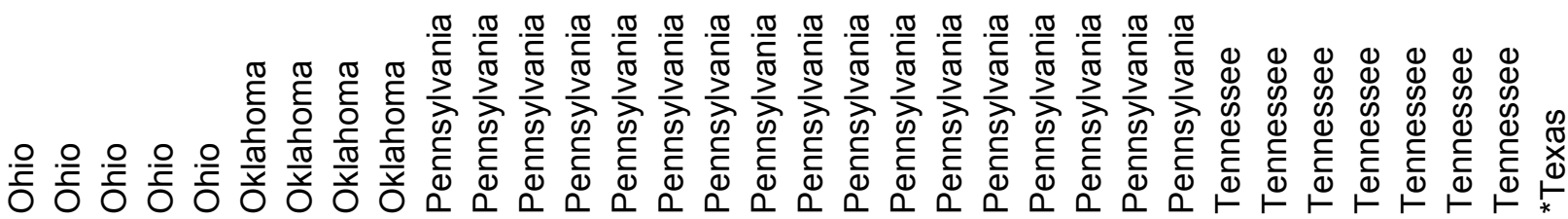




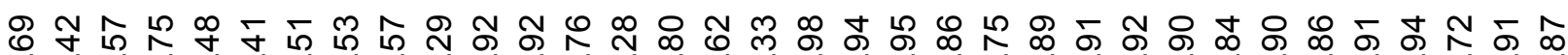

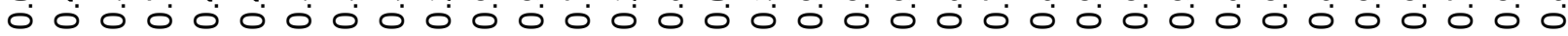

ธ。ำ

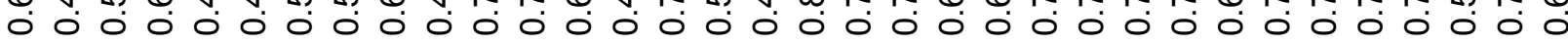

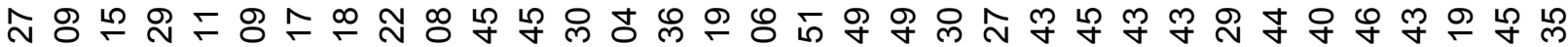

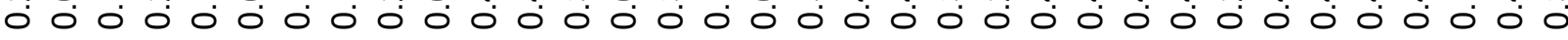

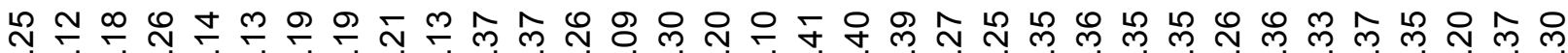

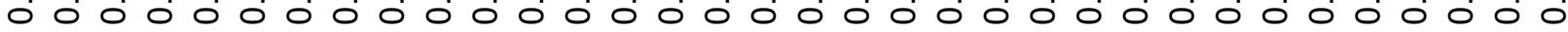

ㅇํㅇ

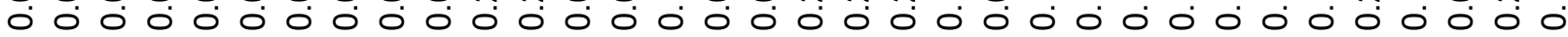

m ָָ

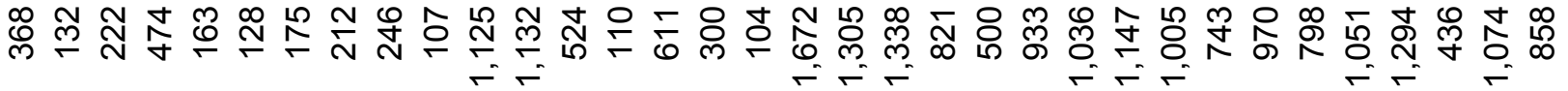

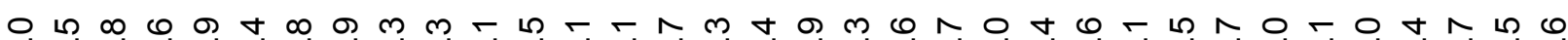

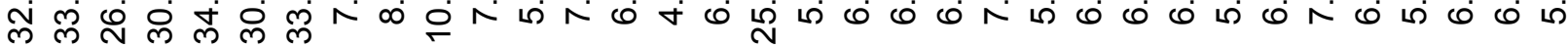

ก 卢

$\infty$ ก மீம்

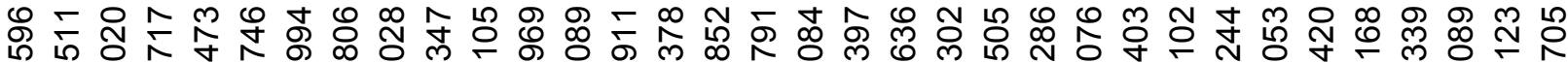
0 0 T

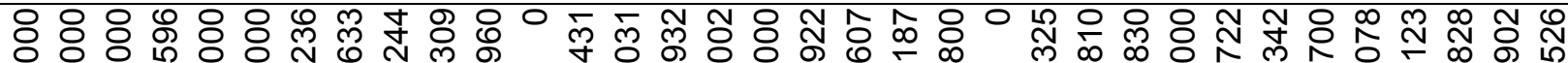
ลิ่ के

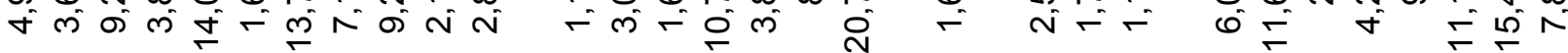

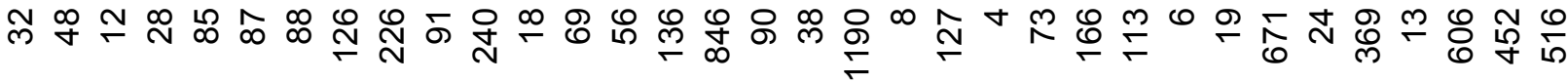
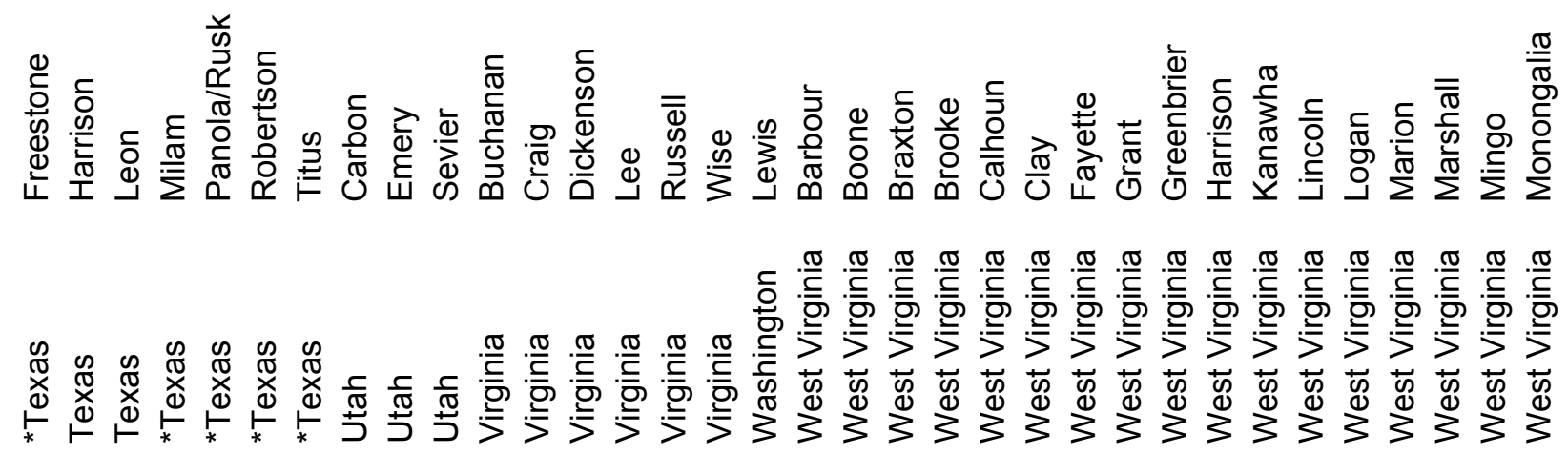
б ஃ \&

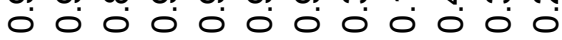

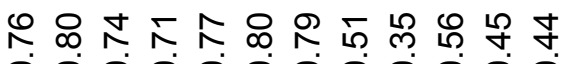
0000000000000

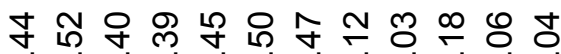
000000000000

윰 규요 m

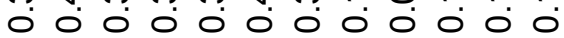

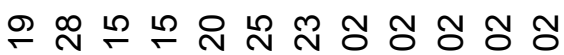

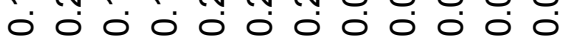

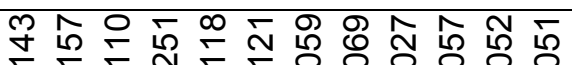

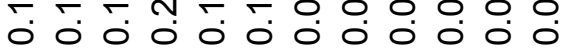

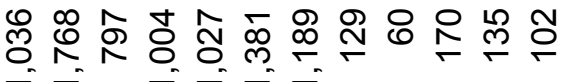
- 4 4 ம்ヘナトம்

๑

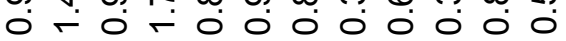

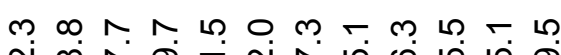
$\infty$ 듀

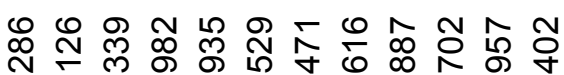

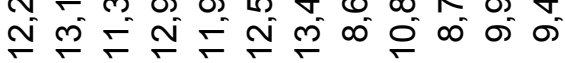

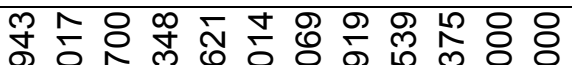

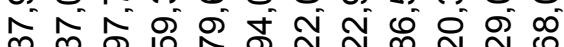
N N N ON J ON

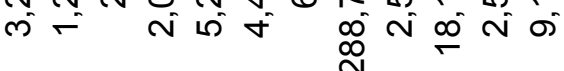

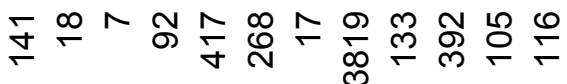
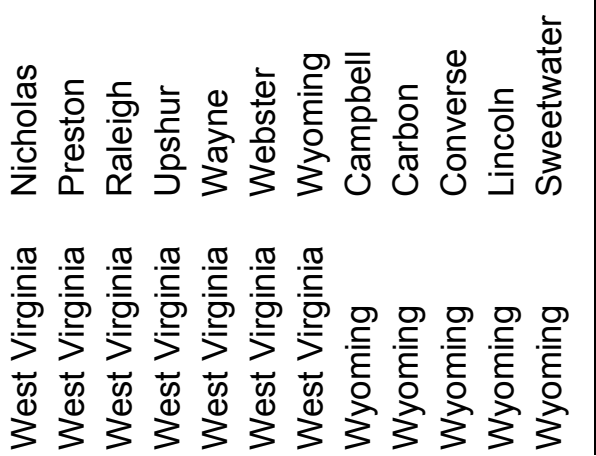

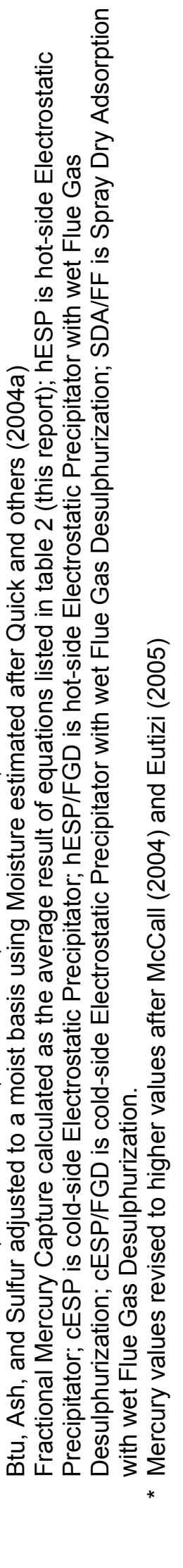




\section{GLOSSARY}

ASTM

Btu

$\mathrm{Btu} / \mathrm{lb}$ m,mm

$\mathrm{Btu}_{\text {net }}$

cESP

ESP

FGD

FF

hESP

$\operatorname{lbs} \mathrm{Cl} / 10^{9} \mathrm{Btu}$

lbs $\mathrm{Hg} / 10^{12}$ Btu

lbs Hg/TW-h
American Society for Testing and Materials.

gross British thermal units per pound coal on a moist, whole-coal basis as reported from the laboratory(multiply by 0.002326 to convert to $\mathrm{MJ} / \mathrm{kg}$ ).

British thermal units per pound coal, on a moist, mineral-matter-free basis calculated as, Btu $/ / b_{m, m m f}=\frac{100(B t u / l b-50 \text { Sulfur })}{(100-[1.08 \text { Ash }-0.55 S])}$, where the sulfur, ash and $\mathrm{Btu} / \mathrm{lb}$ values are on a moist, whole-coal basis.

Net British thermal units per pound coal, reported on a whole-coal, moist basis. Also called the lower heating value, this calculated value is less than the Btu value reported from the laboratory in proportion to the amount of water vapor in gaseous combustion products. It can be calculated as = Btu $-92.7(0.1119$ Moisture + Hydrogen $)$ where both Btu and hydrogen are reported on a moist basis, but hydrogen exlcudes hydrogen in coal moisture.

cold-side Electrostatic Precipitator. (see ESP)

Electrostatic Precipitator. Called a cold-side ESP (cESP) when installed downstream of the air pre-heater (where temperatures typically range from 140 to $160^{\circ} \mathrm{C}$ ) and called a hot-side ESP (hESP) when installed before the air pre-heater (where temperatures typically range from 350 to $450{ }^{\circ} \mathrm{C}$ ).

wet Flue Gas Desulfurization. An emission control technology designed to remove $\mathrm{SO} 2$ from flue gas, usually installed after a particulate collection device; sulfur is removed as flue gas passes through an aqueous, alkaline solution (typically made with lime or limestone).

Fabric Filter. An emission control device, also called a baghouse, that removes solid particles from combustion flue gas.

hot-side Electrostatic Precipitator. (see ESP)

Pounds of chlorine per billion Btu $=\frac{10^{9}}{B t u} \times \frac{p p m C h l o r i n e}{10^{6}}$, where Btu and chlorine values are on the same reporting basis (for example, both dry basis or both moist basis. Multiply by 0.430 to convert to $\mathrm{kg} \mathrm{Cl} / \mathrm{TJ}$.

Pounds of mercury per trillion Btu $=\frac{10^{12}}{B t u} \times \frac{p p m \text { Mercury }}{10^{6}}$, where Btu and mercury values are on the same reporting basis (for example, both dry basis or both moist basis). Multiply by 0.430 to convert to $\mathrm{kg} \mathrm{Hg} / \mathrm{PJ}$.

Pounds mercury per terawatt hour, which is calculated in this report as: $=\frac{10^{12}}{B t u_{n e t}} \times \frac{p p m \text { Mercury }}{10^{6}} \times 10.26$ where both $\mathrm{Btu}_{\text {net }}$ and mercury are reported 
lbs S $/ 10^{6}$ Btu

\begin{tabular}{|c|c|}
\hline COALQUAL & Coal quality database from the U.S. Geological Survey. \\
\hline CTRDB & $\begin{array}{l}\text { Coal Transportation Rate Data Base from the U.S. Energy Information } \\
\text { Administration. }\end{array}$ \\
\hline daf & $\begin{array}{l}\text { A dry, ash-free reporting basis, usually noted as a subscript associated } \\
\text { with a coal assay value. Dry, ash-free basis values are obtained by } \\
\text { multipling, moist, whole-coal assay values by the factor: } \\
\frac{100}{(100-\text { Ash - Moisture })}, \text { where ash and moisture values are on a moist, } \\
\text { whole-coal basis. }\end{array}$ \\
\hline DOE & U.S. Department of Energy. \\
\hline EIA & U.S. Energy Information Administration. \\
\hline EPA & U.S. Environmental Protection Agency. \\
\hline FERC & Federal Energy Regulatory Commission. \\
\hline FERC 423 & $\begin{array}{l}\text { A monthly data set listing the cost and quality of coal delivered to U.S. } \\
\text { power plants. }\end{array}$ \\
\hline ICR & $\begin{array}{l}\text { Information Collection Request. Data collected during } 1999 \text { by the EPA } \\
\text { to assist the development of any rules to limit mercury emissions from } \\
\text { coal-fired utilities. The part } 2 \text { data list coal assay data for coal shipments, } \\
\text { the part } 3 \text { data list measurements of mercury in stack gas. }\end{array}$ \\
\hline ppm & parts per million. Equals $\mu \mathrm{g} / \mathrm{g}$ or $\mathrm{mg} / \mathrm{kg}$. \\
\hline PRB & $\begin{array}{l}\text { Powder River Basin. Refers to coal produced from Campbell, Converse, } \\
\text { and Sheridan Counties, Wyoming as well as Big Horn and Rosebud } \\
\text { Counties, Montana. }\end{array}$ \\
\hline PSU & Pennsylvania State University. \\
\hline SDA & $\begin{array}{l}\text { Spray Dry Adsorption. An emission control technology designed to } \\
\text { remove SO2 from flue gas, gaseous sulfur is converted to a solid sulfate } \\
\text { when an alkaline mist is injected into the flue gas; the solids are then } \\
\text { collected in a particulate filter. Usually used for low-sulfur western coal. }\end{array}$ \\
\hline UGS & Utah Geological Survey \\
\hline USGS & United States Geological Survey. \\
\hline
\end{tabular}

Pounds of sulfur per million Btu $=\frac{10^{6}}{B t u} \times \frac{\% \text { Sulfur }}{100}$, where Btu and sulfur values are on the same reporting basis (for example, both dry basis or both moist basis). Multiply by 0.430 to convert to $\mathrm{kg} \mathrm{S} / \mathrm{GJ}$.

Coal quality database from the U.S. Geological Survey.

Coal Transportation Rate Data Base from the U.S. Energy Information

A dry, ash-free reporting basis, usually noted as a subscript associated with a coal assay value. Dry, ash-free basis values are obtained by multipling, moist, whole-coal assay values by the factor:

$\frac{100}{(100-\text { Ash - Moisture })}$, where ash and moisture values are on a moist, whole-coal basis.

Federal Energy Regulatory Commission.

A monthly data set listing the cost and quality of coal delivered to U.S.

Information Collection Request. Data collected during 1999 by the EPA to assist the development of any rules to limit mercury emissions from coal-fired utilities. The part 2 data list coal assay data for coal shipments, parts per million. Equals $\mu \mathrm{g} / \mathrm{g}$ or $\mathrm{mg} / \mathrm{kg}$.

Powder River Basin. Refers to coal produced from Campbell, Converse, and Sheridan Counties, Wyoming as well as Big Horn and Rosebud Counties, Montana.

Spray Dry Adsorption. An emission control technology designed to remove $\mathrm{SO} 2$ from flue gas, gaseous sulfur is converted to a solid sulfate when an alkaline mist is injected into the flue gas; the solids are then collected in a particulate filter. Usually used for low-sulfur western coal.

\section{United States Geological Survey.}

on a moist basis, and the coefficient, 10.26, corresponds to a nominal heat rate of $35 \%$ (exactly 9,750 gross Btu/kilowatt-hour, which is approximately 10,260 net Btu/kilowatt-hour). 